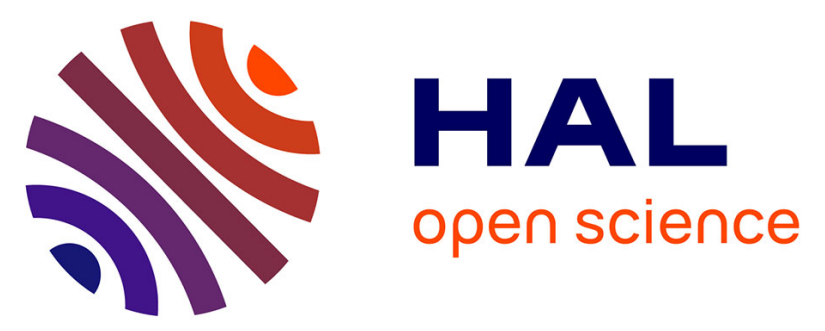

\title{
Toward the Formation of
}

N-Heterocyclic-Carbene-Protected Gold Clusters of Various Nuclearities. A Comparison with Their Phosphine-Protected Analogues from Density Functional Theory Calculations

\author{
Jianyu Wei, J.-F. Halet, Samia Kahlal, Jean-Yves Saillard, Alvaro \\ Munoz-Castro
}

\section{- To cite this version:}

Jianyu Wei, J.-F. Halet, Samia Kahlal, Jean-Yves Saillard, Alvaro Munoz-Castro. Toward the Formation of N-Heterocyclic-Carbene-Protected Gold Clusters of Various Nuclearities. A Comparison with Their Phosphine-Protected Analogues from Density Functional Theory Calculations. Inorganic Chemistry, 2020, 59 (20), pp.15240-15249. 10.1021/acs.inorgchem.0c02219 . hal-02998918

\author{
HAL Id: hal-02998918 \\ https://hal.science/hal-02998918
}

Submitted on 18 Nov 2020

HAL is a multi-disciplinary open access archive for the deposit and dissemination of scientific research documents, whether they are published or not. The documents may come from teaching and research institutions in France or abroad, or from public or private research centers.
L'archive ouverte pluridisciplinaire HAL, est destinée au dépôt et à la diffusion de documents scientifiques de niveau recherche, publiés ou non, émanant des établissements d'enseignement et de recherche français ou étrangers, des laboratoires publics ou privés. 


\section{Towards the Formation of N-Heterocyclic Carbene-}

\section{Protected Gold Clusters of Various Nuclearities. A}

\section{Comparison with their Phosphine-Protected Analogs}

\section{from DFT Calculations}

Jianyu Wei, ${ }^{\dagger}$ Jean-François Halet,${ }^{\dagger}$ Samia Kahlal, ${ }^{\dagger}$ Jean-Yves Saillard ${ }^{*}{ }^{\dagger}$ and Alvaro MuñozCastro* $^{*} \S$

[†] Univ Rennes, CNRS, Institut des Sciences Chimiques de Rennes (ISCR) - UMR 6226, F35000 Rennes, France.

[ §] Grupo de Química Inorgánica y Materiales Moleculares, Facultad de Ingenieria, Universidad Autonoma de Chile, El Llano Subercaseaux 2801, Santiago, Chile

KEYWORDS: Gold, superatoms, NHC, phosphines 
ABSTRACT: The structure and bonding of a series of selected phosphine-protected gold clusters $\left(\mathbf{A u}_{\mathbf{n}}-\mathbf{P}\right)$ of nuclearity varying from $n=6$ to 13 were investigated by DFT calculations and compared to that of the hypothetical homologues in which phosphines were replaced by NHC analogs $\left(\mathbf{A u}_{\mathbf{n}}-\mathbf{C}\right)$. Both $\mathbf{A u _ { n }}-\mathbf{P}$ and $\mathbf{A u}_{n}-\mathbf{C}$ series exhibit similar stabilities and structural features, except for $n=6$ where some differences are noted. The NHC ligands are found even slightly more strongly bonded to the gold core (by a few $\mathrm{kcal} / \mathrm{mol}$ per ligand) than phosphines. Investigation of the optical properties of both series using TD-DFT calculations indicates similarities in the nature and energies of the UV-Vis optical transitions and consequently relatively similar shapes of the simulated spectra, with a general blue-shift tendency when going from $\mathbf{A} \mathbf{u}_{\mathbf{n}}-\mathbf{P}$ to $\mathbf{A} \mathbf{u}_{\mathbf{n}}-\mathbf{C}$. The fluorescence behavior observed experimentally for some of the $\mathbf{A} \mathbf{u}_{\mathbf{n}^{-}}$ $\mathbf{P}$ species is expected to occur also for their $\mathbf{A} \mathbf{u}_{\mathbf{n}}-\mathbf{C}$ analogs, which can be extended to other carbene ligand-protected nanoclusters. Our results show that it should be possible to stabilize gold clusters with $\mathrm{NHC}$ ligands, in relation to the seminal $\mathrm{Au}_{13}$ ligand-protected core, offering novel building blocks for the design of nanostructured materials with various properties. 


\section{Introduction}

Ligated atom-precise gold nanoclusters (AuNCs) are currently the subject of considerable interest. ${ }^{1-7}$ On one side, they represent the lowest size limit of gold nanoparticles (AuNPs), with, in addition, ideal mono-dispersity. They constitute thus interesting models for fundamentally understanding the numerous properties of potential technological interest of larger AuNPs. ${ }^{1-16}$ On the other side, AuNCs have also their own intrinsic interest, due to their specific properties associated with their delocalized 6s electrons. The field of their various chemical, biochemical, physicochemical and physical properties is as large as their extremely rich structural chemistry. ${ }^{1-}$ ${ }^{7}$ Numerous theoretical and experimental research efforts have contributed to the rationalization of their structure and stability towards the design of novel noble-metal nanostructures. ${ }^{17-31}$ It appears obvious that the role played by the AuNC ligand shell is decisive in the stabilization of a given structure for a given electron count. Ligands do not only play the role of passivating the metal core surface, but can also have significant influence on the AuNC structure and properties. Thus, introducing new ligands in the synthetic chemistry of AuNCs is of prime interest, in particular for tuning their optical properties.

From this view point, it is worth noting that N-heterocyclic carbenes (NHC) have been very recently introduced as new protecting ligands of gold clusters. ${ }^{6,32-37}$ In particular, Crudden and coworkers synthezised NHC-protected $\mathrm{Au}_{13}$ superatoms that exhibit large photoluminescent quantum yields. ${ }^{33,34}$ It turns out that one of us recently published a Density Functional Theory (DFT) investigation on the effect of substituting the diphosphine ligands by NHCs in the wellknown $\left[\mathrm{Au}_{13}(\mathrm{dppe})_{5} \mathrm{Cl}_{2}\right]^{3+}$ cluster (dppe $=$ diphenylphosphinethane) ${ }^{38}$ It was found that the substitution does not substantially modify the AuNC stability, but significantly affects the optical 
properties. Thus, NHCs appear to be an interesting alternative to their phosphine isolobal analogs, allowing increasing cluster versatility, owing to the electronic variability of NHCs, which range from strong to weak donor ligands..$^{39-43}$

As a continuation of our first work, ${ }^{38}$ we report here a comprehensive DFT investigation on the substitution of phosphines by NHCs in a series of small and medium size phosphine-protected AuNCs. The analysis is mainly focused on the substitution-induced changes on the structural arrangement, electronic structure and optical (including emissive) properties. The chosen AuNCs phosphine reference series (see Table 1) is composed of the experimentally characterized $\left.\left[\mathrm{Au}_{6}(\mathrm{dppp})_{4}\right]^{2+}{ }^{44,45}\left(\mathbf{A u}_{6}-\mathbf{P}\right), \quad\left[\mathrm{Au}_{8}(\mathrm{dppp})_{4}\right]^{2+}{ }^{46}\left(\mathbf{A u}_{\mathbf{8}} \mathbf{- P}\right), \quad\left[\mathrm{Au}_{8}(\mathrm{dppp})_{4} \mathrm{Cl}_{2}\right]^{2+}{ }^{46} \mathbf{( A u}_{8} \mathbf{C l}_{\mathbf{2}} \mathbf{- P}\right)$, $\left[\mathrm{Au}_{9}\left(\mathrm{PPh}_{3}\right)_{8}\right]^{3+47,48}\left(\mathbf{A u}_{9}-\mathbf{P}\right),\left[\mathrm{Au}_{11}(\mathrm{dppe})_{6}\right]^{3+}{ }^{49}\left(\mathbf{A u}_{11}-\mathbf{P}\right),\left[\mathrm{Au}_{11}\left(\mathrm{PPh}_{3}\right)_{8} \mathrm{Cl}_{2}\right]^{+50,51}\left(\mathbf{A u}_{11} \mathbf{C l}_{2}-\mathbf{P}\right)$, and $\left[\mathrm{Au}_{13}(\mathrm{dppe})_{5} \mathrm{Cl}_{2}\right]^{3+}{ }^{52}\left(\mathbf{A u}_{13} \mathbf{C l}_{2}-\mathbf{P}\right)(\mathrm{dppp}=$ diphenylphosphinepropane). These compounds were chosen because their offer a reasonable range of nuclearity (from 6 to 13), structure types and superatom electron counts (from 4 to 8 - 5d electrons are not considered). Some of them have diphosphines, whereas others have simple phosphines. Some bear chloride ligands whereas the others are homoleptic. Moreover, photoluminescence data are available for most of them. ${ }^{46,47,52,53}$ The hypothetical $\left[\mathrm{Au}_{13}\left(\mathrm{PPh}_{3}\right)_{9} \mathrm{Cl}_{3}\right]^{2+}\left(\mathbf{A u}_{13} \mathbf{C l}_{3}-\mathbf{P}\right)$ compound, which is the phosphine counterpart of several recently characterized $\mathrm{NHC}$ derivatives $\left[\mathrm{Au}_{13}(\mathrm{NHC})_{9} \mathrm{Cl}_{3}\right]^{2+}$ was added to this series. ${ }^{33}$ Thus, we believe that the variety of these compounds makes this series a good reference sampling for investigating the changes occurring upon substituting the phosphine ligands by NHC homologs. These homologs were designed by substituting the mono-phosphines by the mono-carbene N,N'-diisopropylimidazolidene ligands (noted NHC' in the followings, see Scheme 1), taken from the litterature. ${ }^{32}$ The dppe and dppp diphosphine ligands were substituted by their NHC analogs, namely 1,3-bis\{N-isopropylimidazolidenyl $\}$ ethane (di-NHC'e) and 1,3- 
bis $\{\mathrm{N}$-isopropylimidazolidenyl $\}$ propane (di-NHC’p), respectively (Scheme 1 ). These carbenes are representative of standard NHCs and exhibit realistic steric volume. Thus, the computed NHC clusters are: $\left[\mathrm{Au}_{6}\left(\mathrm{di}-\mathrm{NHC}{ }^{\prime} \mathrm{p}\right)_{4}\right]^{2+}\left(\mathrm{Au}_{6}-\mathbf{C}\right), \quad\left[\mathrm{Au}_{8}\left(\mathrm{di}-\mathrm{NHC}^{\prime} \mathrm{p}\right)_{4}\right]^{2+} \quad\left(\mathrm{Au}_{8}-\mathbf{C}\right), \quad\left[\mathrm{Au}_{8}(\mathrm{di}-\right.$ $\left.\left.\mathrm{NHC}^{\prime} \mathrm{p}\right)_{4} \mathrm{Cl}_{2}\right]^{2+} \quad\left(\mathbf{A u}_{8} \mathbf{C l}_{2}-\mathbf{C}\right), \quad\left[\mathrm{Au}_{9}\left(\mathrm{NHC}^{\prime}\right)_{8}\right]^{3+} \quad\left(\mathbf{A u}_{9}-\mathbf{C}\right), \quad\left[\mathrm{Au}_{11}\left(\mathrm{di}-\mathrm{NHC}^{\prime} \mathrm{e}\right)_{6}\right]^{3+} \quad\left(\mathbf{A u}_{11}-\mathbf{C}\right)$, $\left[\mathrm{Au}_{11}\left(\mathrm{NHC}^{\prime}\right)_{8} \mathrm{Cl}_{2}\right]^{+}\left(\mathbf{A u}_{11} \mathbf{C l}_{2}-\mathbf{C}\right),\left[\mathrm{Au}_{13}\left(\mathrm{di}-\mathrm{NHC}^{\prime} \mathrm{e}\right)_{5} \mathrm{Cl}_{2}\right]^{3+}\left(\mathbf{A u}_{13} \mathbf{C l}_{2}-\mathbf{C}\right)$, and $\left[\mathrm{Au}_{13}\left(\mathrm{NHC}^{\prime}\right)_{9} \mathrm{Cl}_{3}\right]^{2+}$ $\left(\mathrm{Au}_{13} \mathrm{Cl}_{3}-\mathrm{C}\right)$.

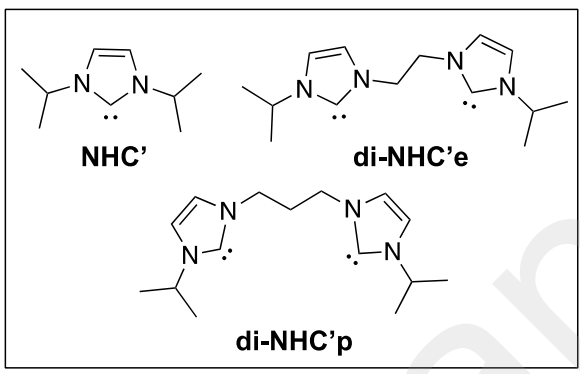

Scheme 1. NHC Ligands Considered in the Calculations

Table 1. Structurally Characterized Phosphine-protected AuNCs from which Models Were Considered in our Calculations

\begin{tabular}{|c|c|c|c|c|}
\hline Compound & Abbreviation & \begin{tabular}{|l} 
Number of $6 \mathrm{~s}$ \\
$\mathrm{(Au})$ electrons
\end{tabular} & Structure of the $\mathrm{Au}_{\mathrm{n}}$ core & Ref. \\
\hline$\left[\mathrm{Au}_{6}(\mathrm{dppp})_{4}\right]^{2+}$ & $\mathbf{A u _ { 6 } - \mathbf { P }}$ & 4 & edge-bridged tetrahedron & 44,45 \\
\hline$\left[\mathrm{Au}_{8}(\mathrm{dppp})_{4}\right]^{2+}$ & $\mathrm{Au}_{8}-\mathrm{P}$ & 6 & edge-sharing tri-tetrahedron & 46 \\
\hline$\left[\mathrm{Au}_{8}(\mathrm{dppp})_{4} \mathrm{Cl}_{2}\right]^{2+}$ & $\mathrm{Au}_{8} \mathrm{Cl}_{2}-\mathrm{P}$ & 4 & $\begin{array}{l}\text { bicapped edge-sharing bi- } \\
\text { tetrahedron }\end{array}$ & 46 \\
\hline$\left[\mathrm{Au}_{9}\left(\mathrm{PPh}_{3}\right)_{8}\right]^{3+}$ & $\mathbf{A u}_{9}-\mathbf{P}$ & 6 & bicapped centered chair & 47,48 \\
\hline$\left[\mathrm{Au}_{11}(\mathrm{dppe})_{6}\right]^{3+}$ & $\mathbf{A u} \mathbf{u}_{11}-\mathbf{P}$ & 8 & $\begin{array}{l}\text { doubly-bridged bicapped } \\
\text { centered chair }\end{array}$ & 49 \\
\hline$\left[\mathrm{Au}_{11}\left(\mathrm{PPh}_{3}\right)_{8} \mathrm{Cl}_{2}\right]^{+}$ & $\mathrm{Au}_{11} \mathrm{Cl}_{2}-\mathrm{P}$ & 8 & incomplete centered icosahedron & 50,51 \\
\hline$\left[\mathrm{Au}_{13}(\mathrm{dppe})_{5} \mathrm{Cl}_{2}\right]^{3+}$ & $\mathrm{Au}_{13} \mathrm{Cl}_{2}-\mathrm{P}$ & 8 & centered icosahedron & 52 \\
\hline$\left[\mathrm{Au}_{13}\left(\mathrm{PPh}_{3}\right)_{9} \mathrm{Cl}_{3}\right]^{2+}$ & $\mathrm{Au}_{13} \mathrm{Cl}_{3}-\mathrm{P}^{\mathrm{a}}$ & 8 & centered icosahedron & 33 \\
\hline
\end{tabular}

(a) Structure modelized from that of Crudden's NHC derivative $\left[\mathrm{Au}_{13}(\mathrm{NHC})_{9} \mathrm{Cl}_{3}\right]^{2+33}$ 


\section{Computational Details}

Geometry optimizations were carried out at the Density Functional Theory (DFT) level ${ }^{54}$ with the addition of Grimme's D3 empirical corrections ${ }^{55}$ in order to take into account dispersion effects. The Amsterdam Density Functional $\operatorname{code}^{56}$ (ADF2017), incorporating the relativistic scalar corrections via the ZORA Hamiltonian was used. ${ }^{57}$ The all-electron triple- $\xi$ Slater basis set plus a polarization function (STO-TZP), ${ }^{58}$ were used, together with the Becke-Perdew (BP86) $)^{59,60}$ exchange-correlation functional. This functional was chosen for its good performance in reproducing cluster ground state geometries and its reasonable CPU time demand. ${ }^{19}$ An energy convergence criterion of $5 \times 10^{-5}$ Hartree and a radial convergence criterion of $5 \times 10^{-3} \AA$ were employed. All the optimized structures were confirmed as true minima on their potential energy surface by analytical vibration frequency calculations. All the computed species have a closedshell ground state. The Gaussian16 package ${ }^{61}$ was used to calculate natural atomic orbital (NAO) populations and Wiberg bond indices (WBI) using the ADF-optimized geometries with its NBO6.0 module, ${ }^{62}$ with the Def2-SVP ${ }^{63}$ basis set and the BP86 functional. In order to reduce computational efforts, the Gaussian16 package was also used for calculating the UV-Vis optical transitions by time-dependent density functional theory ${ }^{64}$ (TD-DFT) calculations, using the Def2-SVP ${ }^{63}$ basis set (which includes effective core potentials accounting for scalar relativistic effects) and the B3LYP functional. ${ }^{65}$ The choice of this functional was made after having tested several of them, namely B3LYP, ${ }^{65} \mathrm{BP} 86,{ }^{59,60}$ and LB94, ${ }^{66}$ with respect to the experimental spectra of the phosphine-protected AuNCs listed in Table 1. Similar trends were found for the three functionals, but the B3LYP-computed optical transitions were found to be in the closest quantitative agreement with experiment. The UV-Vis spectra were simulated from the computed 
TD-DFT transition energies and their oscillator strength by using the SWizard program, ${ }^{67}$ each transition being associated with a Gaussian function of half-height width equal to $3000 \mathrm{~cm}^{-1}$, a value that best reproduces experimental spectra. To calculate the fluorescence emission wavelengths, the geometry of the excited singlet states was optimized at the TD-DFT/B3LYP level with the Gaussian16 program. To compute the phosphorescence emission wavelengths, the geometry of the triplet state was calculated at the DFT/BP86 level with ADF2017 and its energy and that of the ground state were recalculated for this geometry as single points at the B3LYP level with Gaussian16. To compute the energy differences between the singlet and triplet exited states, the ADF optimized triplet exited geometries were re-calculated via single point calculations using Gaussian 16.

\section{Results and Discussion}

\subsection{Structures and Bonding Modes}

The geometries of the phosphine-protected AuNCs $\left(\mathbf{A u}_{\mathbf{n}}-\mathbf{P}\right)$ and their NHC homologs $\left(\mathbf{A u}_{\mathbf{n}}-\mathbf{C}\right)$ were optimized and compared. The former are found to be in good agreement with their corresponding X-ray structures..$^{33,44,46,47,49,51,52}$ Together with those of their NHC homologs $\left(\mathbf{A u}_{\mathbf{n}^{-}}\right.$ C), they are shown in Figure 1. Their corresponding MO diagrams are represented in the form of density-of-states (DOS) plots in Figures S1-S6 (see also Figures S9-S16). They all exhibit similar features, with the $5 \mathrm{~d}(\mathrm{Au})$ states contributing mainly to the large band below the HOMO and the $6 \mathrm{~s} / 6 \mathrm{p}(\mathrm{Au})$ to the lowest unoccupied states. As examples, those of the smallest $\mathbf{A u}_{\mathbf{6}}-\mathbf{X}$ and the largest $\mathbf{A u}_{13} \mathbf{C l}_{2}-\mathbf{X}$ species (X $=\mathrm{P}, \mathrm{C}$ ) are shown in Figure 2. The HOMOs and LUMOs of the computed $\mathbf{A u _ { n }}-\mathbf{P}$ and $\mathbf{A u _ { n }}-\mathbf{C}$ species are pictured in Figures S7 and S8, respectively. 

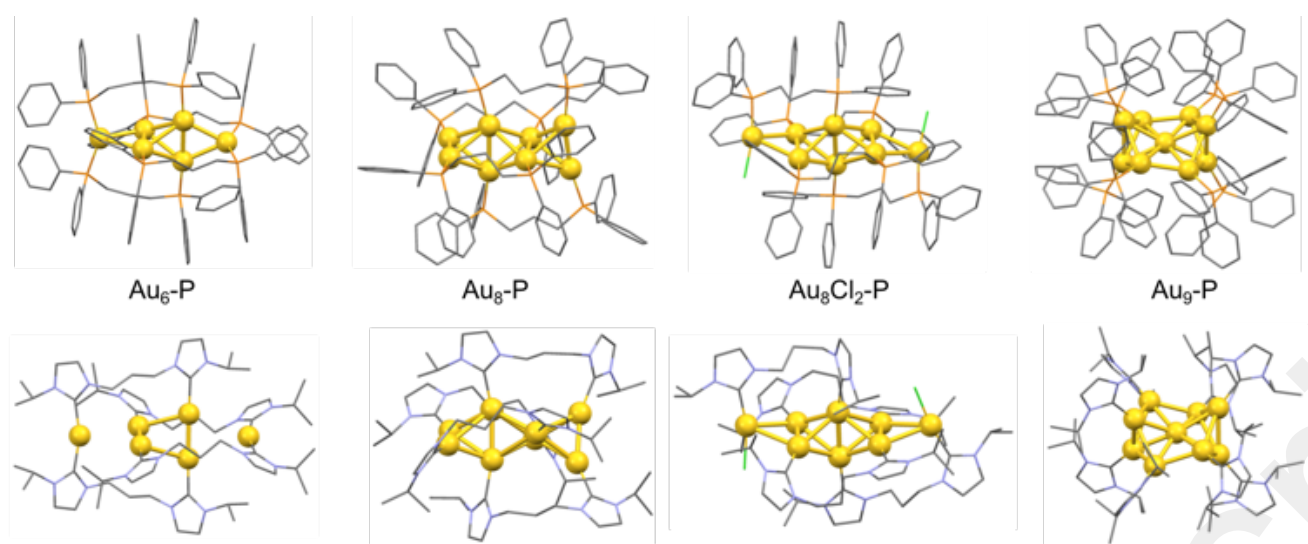

$\mathrm{Au}_{8} \mathrm{Cl}_{2}-\mathrm{P}$

$\mathrm{Au}_{9}-\mathrm{P}$

$\mathrm{Au}_{6}-\mathrm{C}$
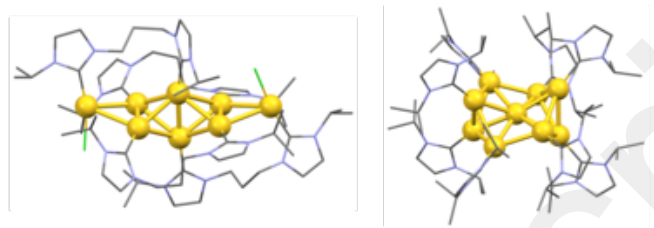

$\mathrm{Au}_{8}-\mathrm{C}$

$\mathrm{Au}_{8} \mathrm{Cl}_{2}-\mathrm{C}$

$\mathrm{Au}_{9}-\mathrm{C}$
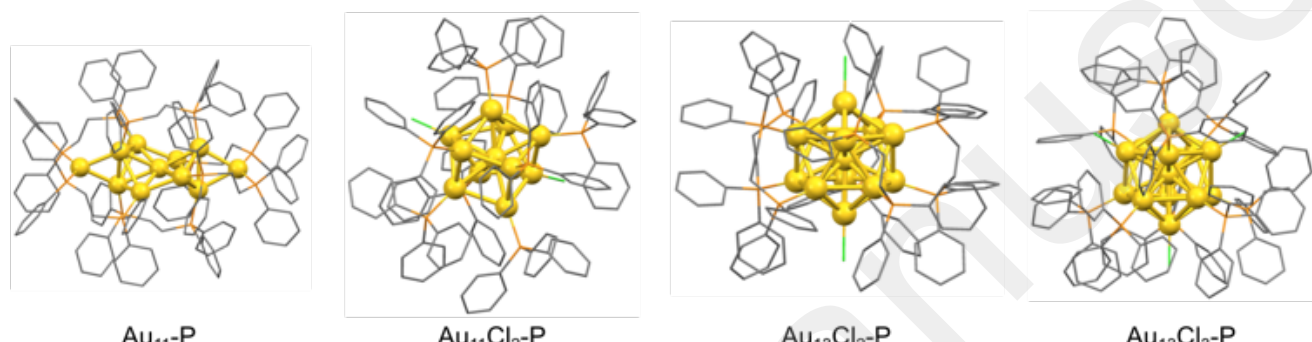

$\mathrm{Au}_{11}-\mathrm{P}$
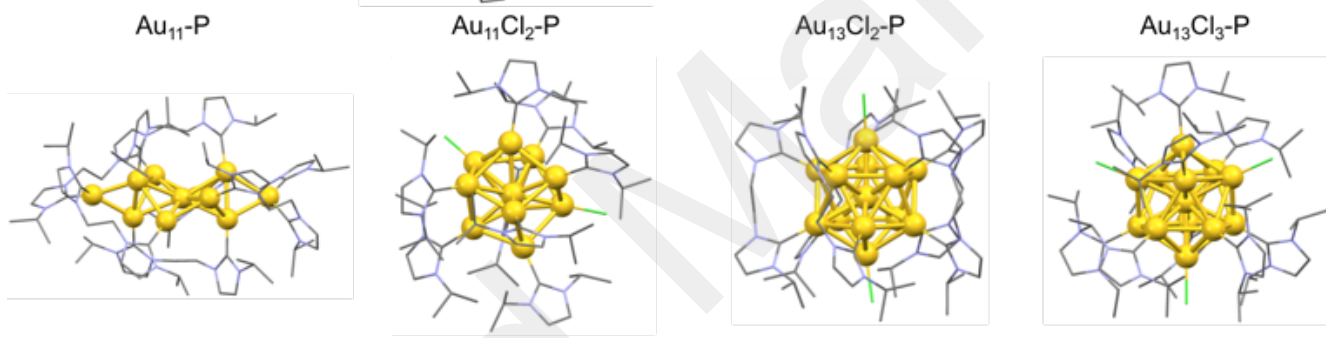

$\mathrm{Au}_{11}-\mathrm{C}$

$\mathrm{Au}_{11} \mathrm{Cl}_{2}-\mathrm{C}$

$\mathrm{Au}_{13} \mathrm{Cl}_{2}-\mathrm{C}$

$\mathrm{Au}_{13} \mathrm{Cl}_{3}-\mathrm{C}$

Figure 1. Optimized geometries of the computed $\mathbf{A} \mathbf{u}_{\mathbf{n}}-\mathbf{X}$ clusters $(X=P, C)$. 

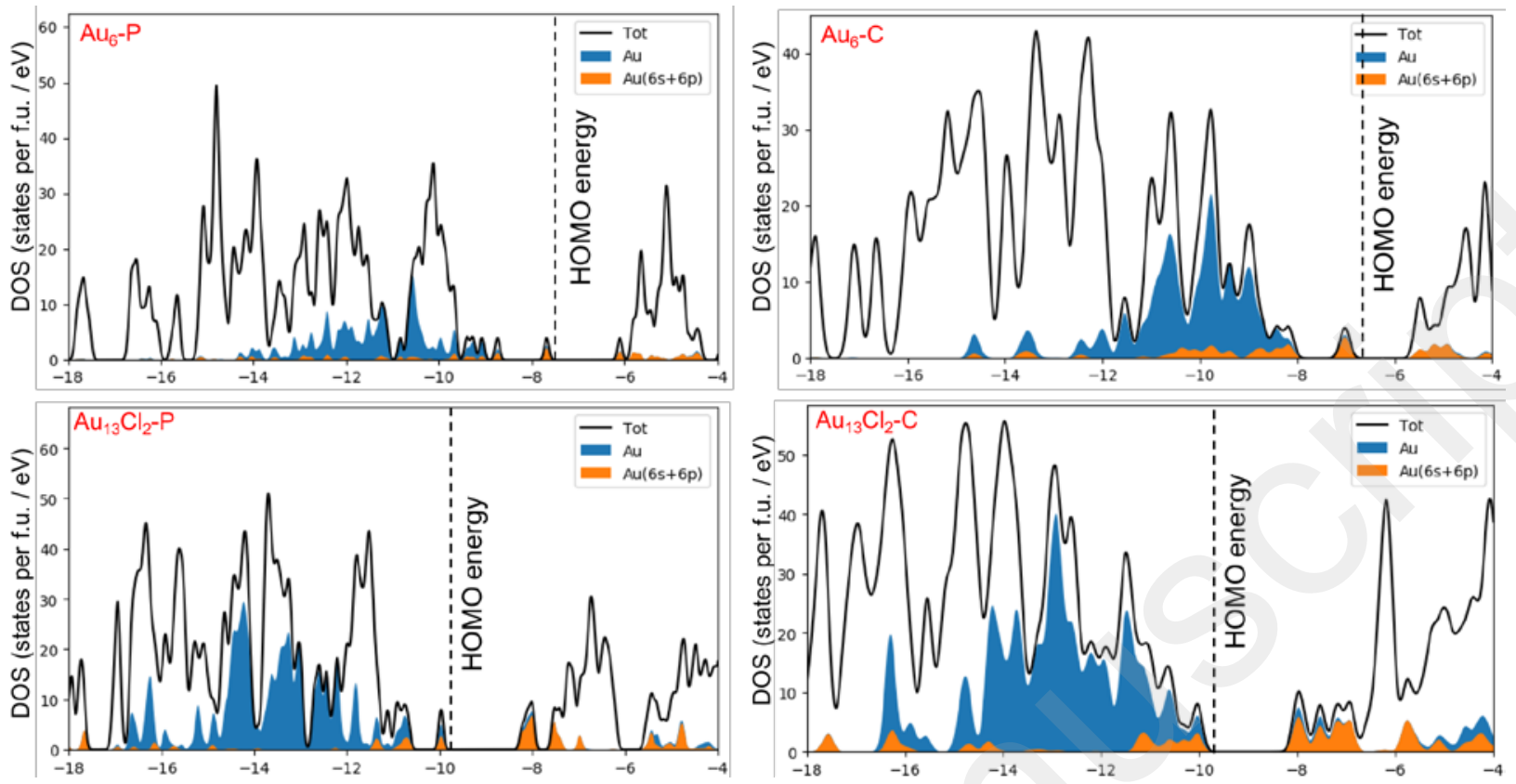

Figure 2. Density of states of $\mathbf{A u}_{6}-\mathbf{X}$ (top) and $\mathbf{A u}_{13} \mathbf{C l}_{2}-\mathbf{X}$ (bottom) $(\mathrm{X}=\mathrm{P}, \mathrm{C})$. Gaussian full width at half maximum: $0.05 \mathrm{eV}$. The dotted line corresponds to the energy of the HOMO.

The core structure of $\mathbf{A u}_{\mathbf{6}}-\mathbf{P}$ consists of an edge-bridged tetrahedron (Figure 1). Whereas its Xray structure is of $S_{4}$ symmetry, its DFT-optimized geometry was found to be slightly distorted into $D_{2}$ symmetry. In a first approximation, the computed data given in Table 2 are consistent with a view of $\mathbf{A u}_{6}-\mathbf{P}$ made of two $\mathrm{R}_{3} \mathrm{P}-\mathrm{Au}(0)-\mathrm{Au}(0)-\mathrm{PR}_{3}$ sub-systems (each containing a 2 electron/2-center bond) and two $\mathrm{R}_{3} \mathrm{P}-\mathrm{Au}(\mathrm{I})-\mathrm{PR}_{3}$ units. In both fragment types, the 14-electron gold centers adopt the (approximately) linear ' $\mathrm{ML}_{2}$ ' coordination mode expected to favor its stability for this particular electron count. ${ }^{68}$ This is confirmed by the nature of the HOMO $\left(b_{1}\right)$ and HOMO-1 (a) of $\mathbf{A u}_{6}-\mathbf{P}$, which can be described as the out-of-phase and in-phase combinations, respectively, of the $\sigma(\mathrm{Au}-\mathrm{Au})$ bonding orbitals of the two $\mathrm{R}_{3} \mathrm{P}-\mathrm{Au}(0)-\mathrm{Au}(0)-\mathrm{PR}_{3}$ moieties (Figure S7). These orbitals, of large 6s/6p character, are moderately delocalized on the $\mathrm{R}_{3} \mathrm{P}-\mathrm{Au}(\mathrm{I})-\mathrm{PR}_{3}$ fragments, suggesting that the 4 electrons remain principally located on the two 
short $\mathrm{Au}-\mathrm{Au}$ bonds of the $\mathrm{Au}_{4}$ tetrahedron, as also confirmed by the much smaller Wiberg bond indices of the other Au-Au contacts (Table 2). It thus can be concluded that these longer $\mathrm{Au}-\mathrm{Au}$ contacts are largely the result of metallophilic interactions. The LUMO (a) is also of important 6s/6p character and has significant localization on the two bridging $\mathrm{Au}$ atoms. $\mathbf{A u}_{\mathbf{6}}-\mathbf{C}$ differs from $\mathbf{A u}_{6}-\mathbf{P}$ in the fact that each of its two L-Au(0)-Au(0)-L and two L-Au(I)-L fragments are even less interacting with the others (see data in Table 2), so that they can be considered as almost independent from each other. Nevertheless, the HOMO $\left(b_{1}\right)$ and HOMO-1 (a) of $\mathbf{A u}_{6}-\mathbf{C}$ are similar to their $\mathbf{A u}_{\mathbf{6}}-\mathbf{P}$ counterparts (Figure S8). The LUMO and LUMO+1 are ligand-based levels. Although localized in part on the bridging Au atoms, the LUMO is different from the LUMO of $\mathbf{A u}_{6}-\mathbf{P}$. The LUMO+2 (a), mainly localized on the outer Au atoms, is the counterpart of the $\mathbf{A u}_{6}-\mathbf{P}$ LUMO. 
Table 2. Relevant Computed Data for the $\left[A u_{6} L_{4}\right]^{2+}$ Clusters $\left(L=\operatorname{dppp}\left(A u_{6}-P\right)\right.$ and $L=$ diNHC'p $\left.\left(\mathrm{Au}_{6}-\mathrm{C}\right)\right)$. $A u_{t}$ and $\mathrm{Au}_{\mathrm{b}}$ Designate the Atoms of the Central Tetrahedron and the Bridging Atoms, Respectively. Experimental Interatomic Distances of $A_{u_{6}}-\mathbf{P}$ Are Provided for Comparison

\begin{tabular}{|c|c|c|c|c|}
\hline & & $\mathbf{A} \mathbf{u}_{6}-\mathbf{P} \exp ^{44}\left(S_{4}\right)$ & $\mathbf{A u _ { 6 }}-\mathbf{P}\left(D_{2}\right)$ & $\mathbf{A u}_{6}-\mathbf{C}\left(D_{2}\right)$ \\
\hline \multirow{6}{*}{ 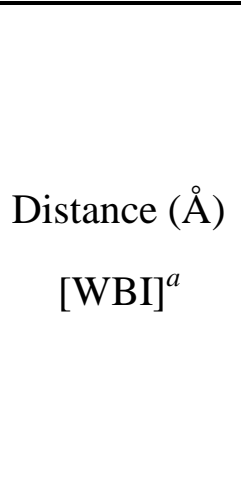 } & \multirow{4}{*}{$A u_{t}-A u_{t}$} & $2.630 \times 2$ & $2.630[0.302] \times 2$ & $2.561[0.462] \times 2$ \\
\hline & & $2.923 \times 2$ & $2.861[0.032] \times 2$ & $3.178[0.019] \times 2$ \\
\hline & & $2.923 \times 2$ & $2.972[0.023] \times 2$ & $3.390[0.011] \times 2$ \\
\hline & & av. 2.825 & av. $2.821[0.119]$ & av. $3.043[0.164]$ \\
\hline & $A u_{b}-A u_{t}$ & $2.798 \times 4$ & $2.790[0.090] \times 4$ & $3.601[0.013] \times 4$ \\
\hline & Au-L & av. 2.378 & av. $2.332[0.391]$ & av. 2.069 [0.441] \\
\hline \multicolumn{2}{|c|}{ HOMO-LUMO gap (eV) } & & 1.58 & 1.53 \\
\hline \multirow{3}{*}{$\mathrm{NAO}^{b}$ charge } & $\mathrm{Au}_{\mathrm{t}}$ & & $-0.02 \times 4$ & $-0.04 \times 4$ \\
\hline & $\mathrm{Au}_{\mathrm{b}}$ & & $+0.27 \times 2$ & $+0.42 \times 2$ \\
\hline & $\mathrm{L}$ & & $+0.39 \times 4$ & $+0.33 \times 4$ \\
\hline
\end{tabular}

${ }^{\mathrm{a}}$ Wiberg bond index. ${ }^{\mathrm{b}}$ Natural atomic orbital.

The core structure of $\mathbf{A u}_{\mathbf{8}}-\mathbf{P}$ consists of three edge-sharing linearly arranged tetrahedra (Figure 1). Its ideal symmetry is $S_{4}$, whereas after relaxation its symmetry is lowered to $C_{2}$. It can be described as made of four quasi-linear L-Au-Au-L units packed perpendicularly along a common pseudo- $S_{4}$ axis in a staggered fashion. The shortest Au-Au distances are those within these L-AuAu-L fragments. The favored electron count for an $\mathrm{Au}_{4}$ tetrahedron is $2,{ }^{69}$ so it is expected that the 6 electrons of $\mathbf{A u}_{\mathbf{8}}-\mathbf{P}$ are delocalized over the three tetrahedra. This is supported by the AuAu WBIs given in Table 3 that are all significant, contrarily to the case of $\mathbf{A} \mathbf{u}_{\mathbf{6}}-\mathbf{P}$ (Table 2). A more detailed analysis of their disparity and examination of the NAO charges tend to favor the view of a 2-electron central tetrahedron $\left[\mathrm{Au}_{4}\left(\mathrm{PR}_{3}\right)_{4}\right]^{2+}$ interacting in a moderate but significant 
covalent way with two linear $\mathrm{R}_{3} \mathrm{P}-\mathrm{Au}(0)-\mathrm{Au}(0)-\mathrm{PR}_{3}$ units. The HOMO $(a)$ and HOMO-1 $(b)$, of large 6s/6p character, can be associated with the two outer $\mathrm{Au}(0)-\mathrm{Au}(0)$ bonding pairs, partly delocalized on the central tetrahedron (Figure S7). It was not possible to identify a unique orbital associated with the third bonding pair, because of orbital mixing, but several 5d-type levels present some non-negligible 6s/6p bonding character within the central tetrahedron. The LUMO and LUMO+1, both of $b$ symmetry, are 6s/6p Au-Au antibonding orbitals.

As for the $\mathrm{Au}_{6}$ systems described above, substituting the phosphines in $\mathbf{A} \mathbf{u}_{\mathbf{8}}-\mathbf{P}$ by $\mathrm{NHC}$ ligands tends to reinforce the $\mathrm{Au}-\mathrm{Au}$ bonding in the four $\mathrm{R}_{3} \mathrm{P}-\mathrm{Au}-\mathrm{Au}-\mathrm{PR}_{3}$ units and weakens somewhat the other $\mathrm{Au}-\mathrm{Au}$ contacts, but the effect is not as strong as in the $\mathrm{Au}_{6}$ systems. The HOMO and HOMO-1 of $\mathbf{A u}_{\mathbf{8}}-\mathbf{C}$ are the counterparts of those of $\mathbf{A} \mathbf{u}_{\mathbf{8}}-\mathbf{P}$. The LUMO+2 and LUMO of $\mathbf{A} \mathbf{u}_{\mathbf{8}}-\mathbf{C}$ are the counterparts of the LUMO and LUMO+1 of $\mathbf{A u}_{\mathbf{8}}-\mathbf{P}$ (Figure S8). As for the $\mathrm{Au}_{6}$ systems, a slightly smaller HOMO-LUMO gap is computed when phosphines are substituted by NHC ligands. 
Table 3. Relevant Computed Data for $\left[A u_{8} L_{4}\right]^{2+}$ Clusters $\left(L=\operatorname{dppp}\left(A u_{8}-P\right)\right.$ and $L=$ diNHC'p $\left.\left(\mathrm{Au}_{8}-\mathrm{C}\right)\right)$. Experimental Interatomic Distances of $\mathrm{Au}_{8}-\mathrm{P}$ Are Provided for Comparison

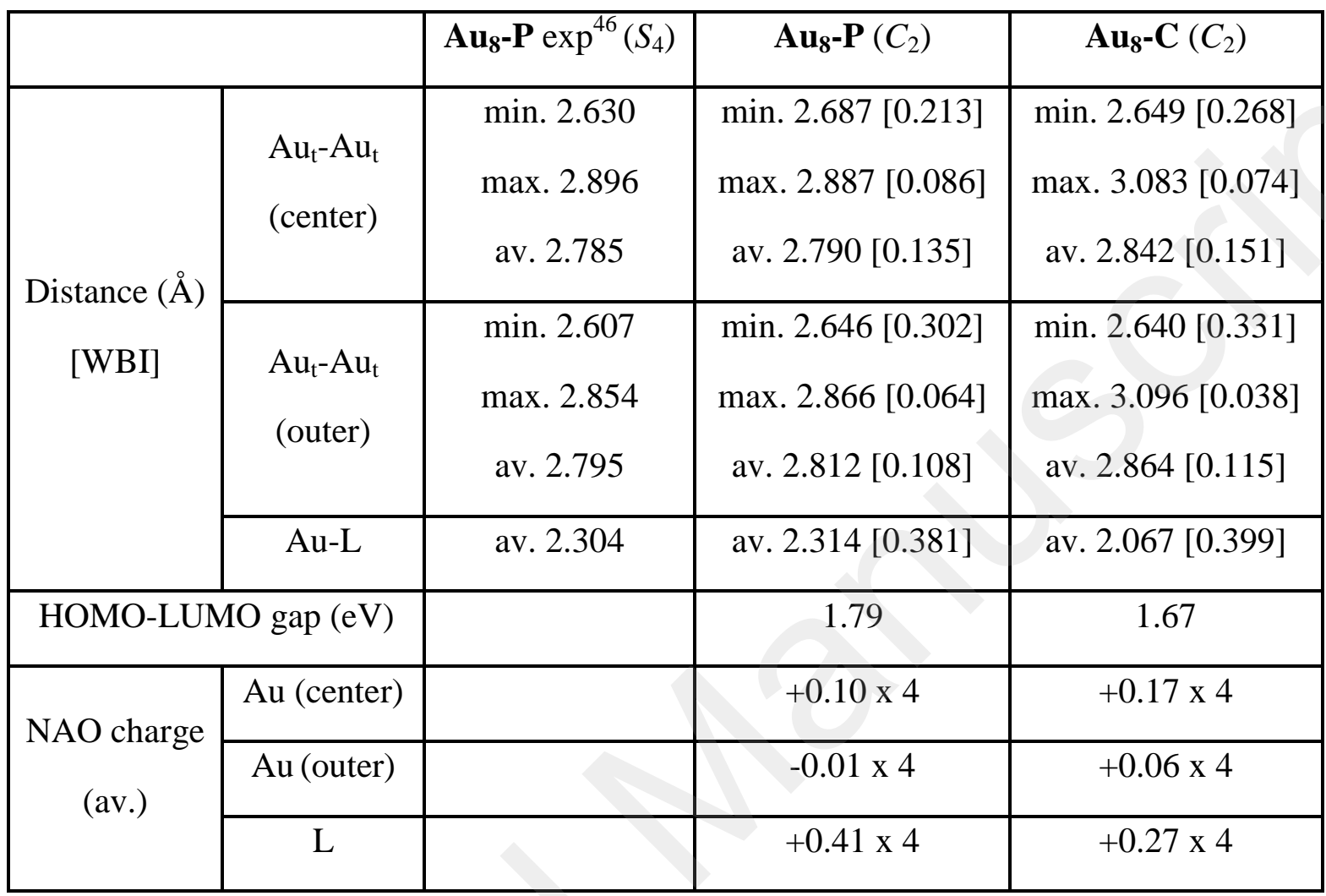

The structural arrangement of the $\mathbf{A u}_{\mathbf{8}} \mathbf{C l}_{\mathbf{2}} \mathbf{- P}$ cluster differs from that of $\mathbf{A} \mathbf{u}_{\mathbf{8}}-\mathbf{P}$ (Figure 1). It exhibits a core made of two edge-sharing tetrahedra capped on both sides by two nearly linear $\mathrm{R}_{3} \mathrm{P}-\mathrm{Au}_{\mathrm{b}}-\mathrm{Cl}$ units. Its ideal symmetry is $D_{2 h}$, but DFT computations found it slightly distorted into $C_{1}$ after relaxation. This is a 4-electron species, and the NAO charge distribution (Table 4) indicates that the two bridging atoms can be considered as $\mathrm{Au}_{\mathrm{b}}(\mathrm{I})$ centers. The 4 electrons can thus be associated with the bi-tetrahedron, where they are predominantly located on the $\mathrm{R}_{3} \mathrm{P}$ $\mathrm{Au}_{\mathrm{m}}-\mathrm{Au}_{\mathrm{m}}-\mathrm{PR}_{3}$ and $\mathrm{R}_{3} \mathrm{P}-\mathrm{Au}_{\mathrm{s}}-\mathrm{Au}_{\mathrm{s}}-\mathrm{PR}_{3}$ bonds, as shown by the corresponding WBIs. This is in line with the composition and shape of the HOMO and HOMO-1 (Figure S7) orbitals of $\mathbf{A u}_{\mathbf{8}} \mathbf{C l}_{\mathbf{2}} \mathbf{- P}$, which are associated with these 4 electrons. The LUMO and LUMO+1 are 6s/6p in composition associated with the bridging $\mathrm{Au}_{\mathrm{b}}$ atoms and the bi-tetrahedron, respectively (Figure S7). 
Compound $\mathbf{A u}_{8} \mathbf{C l}_{2}-\mathbf{C}$ has similar arrangement and electronic structure as its phosphine homolog (Figure S8). When going from $\mathbf{A u}_{8} \mathbf{C l}_{2}-\mathbf{P}$ to $\mathbf{A u}_{8} \mathbf{C l}_{2}-\mathbf{C}$, a strengthening of the $\mathrm{R}_{3} \mathrm{PAu}-\mathrm{AuPR} \mathrm{R}_{3}$ bond and some weakening of the other Au-Au bonds is observed, a tendency already noted in the previous clusters, but less pronounced in the present systems. In contrast with the previous $\mathrm{Au}_{6}$ and $\mathrm{Au}_{8}$ systems, a larger HOMO-LUMO gap is computed when phosphine ligands are substituted by NHC ligands.

Table 4. Relevant Computed Data for $\left[\mathrm{Au}_{8} \mathrm{Cl}_{2} \mathrm{~L}_{4}\right]^{2+}$ Clusters $\left(\mathrm{L}=\operatorname{dppp}\left(\mathrm{Au}_{8} \mathrm{Cl}_{2}-\mathrm{P}\right)\right.$ and $\mathrm{L}=$ di-NHC'p $\left(\mathrm{Au}_{8} \mathrm{Cl}_{2}-\mathrm{C}\right)$ ). Experimental Interatomic Distances of $\mathrm{Au}_{8} \mathrm{Cl}_{2}-\mathrm{P}$ Are Provided for Comparison. $\mathrm{Au}_{\mathrm{m}}$ and $\mathrm{Au}_{\mathrm{s}}$ Designate the Middle and Side Atoms of the Bi-tetrahedron, Respectively, and $\mathrm{Au}_{\mathrm{b}}$ the Bridging Atoms

\begin{tabular}{|c|c|c|c|c|}
\hline & $\mathbf{A u _ { 8 }} \mathbf{C l}_{2}-\mathbf{P} \exp ^{46}\left(D_{2 h}\right)$ & $\mathbf{A u}_{8} \mathbf{C l}_{2}-\mathbf{P}\left(C_{1}\right)$ & $\mathbf{A u}_{8} \mathbf{C l}_{2}-\mathbf{C}\left(C_{1}\right)$ \\
\hline \multirow{6}{*}{$\begin{array}{c}\text { Distance }(\AA) \\
\text { [WBI] }\end{array}$} & $A u_{m}-A u_{m}$ & 2.648 & av. 2.676 [0.196] & av. 2.667 [0.230] \\
\hline & $A u_{s}-A_{s}$ & av. 2.654 & av. $2.692[0.244]$ & av. 2.691 [0.273] \\
\hline & $\mathrm{Au}_{\mathrm{m}}-\mathrm{Au}_{\mathrm{s}}$ & av. 2.821 & av. $2.849[0.089]$ & av. 2.878 [0.093] \\
\hline & $A u_{s}-A u_{b}$ & av. 3.026 & av. $2.960[0.042]$ & av. $3.034[0.032]$ \\
\hline & Au-L & av. 2.302 & av. $2.311[0.441]$ & av. $2.062[0.449]$ \\
\hline & $\mathrm{Au}-\mathrm{Cl}$ & av. 2.289 & av. 2.348 [0.394] & av. $2.346[0.423]$ \\
\hline \multicolumn{2}{|c|}{ HOMO-LUMO gap (eV) } & & 1.87 & 2.03 \\
\hline \multirow{5}{*}{$\begin{array}{c}\text { NAO charge } \\
\text { (av.) }\end{array}$} & $\mathrm{Au}_{\mathrm{m}}$ & & $+0.14 \times 2$ & $+0.22 \times 2$ \\
\hline & $\mathrm{Au}_{\mathrm{s}}$ & & $+0.05 \times 4$ & $+0.12 \times 4$ \\
\hline & $\mathrm{Au}_{\mathrm{b}}$ & & $+0.30 \times 2$ & $+0.37 \times 2$ \\
\hline & $\mathrm{L}$ & & $+0.49 \times 4$ & $+0.35 \times 4$ \\
\hline & $\mathrm{Cl}$ & & $-0.52 \times 2$ & $-0.54 \times 2$ \\
\hline
\end{tabular}

The 6-electron $\mathbf{A} \mathbf{u}_{9}-\mathbf{P}$ cluster that we investigated (Figure 1) is generally described as a bicapped centered chair, ${ }^{47,48}$ that is, a centered $\mathrm{Au}_{6}$ chair-like ring with two opposite vertices 
capped by two supplementary gold atoms. It has an isomer exhibiting a centered crown ${ }^{70}$ which is not discussed here. The whole structure of $\mathbf{A} \mathbf{u}_{9}-\mathbf{P}$ is of ideal $D_{2}$ symmetry. Analysis of the data in Table 5 and its Kohn-Sham orbitals allows us to describe $\mathbf{A u}_{9}-\mathbf{P}$ as an oblate-distorted superatom, with corresponding $1 \mathrm{~S}^{2} 1 \mathrm{P}^{4}$ closed-shell electron configuration. The HOMO $\left(b_{2}\right)$ and the HOMO-1 $\left(b_{1}\right)$ are the $\mathrm{P}_{\mathrm{x}}$ and $\mathrm{P}_{\mathrm{y}}$ orbitals, whereas the LUMO+1 is the $\mathrm{P}_{\mathrm{z}}$ counterpart (Figure S7). The LUMO is the $\mathrm{D}_{\mathrm{x} 2-\mathrm{y} 2}$ orbital. The electronic structure of $\mathbf{A} \mathbf{u}_{9}-\mathbf{C}$ is the same as that of $\mathbf{A u}_{9}-\mathbf{P}$, except the LUMO and LUMO+1, which are inverted in energy (Figure S8). Again, a small strengthening of the $\mathrm{Au}-\mathrm{Au}$ bonding is noted when going from $\mathbf{A} \mathbf{u}_{9}-\mathbf{P}$ to $\mathbf{A} \mathbf{u}_{9}-\mathbf{C}$. Comparable HOMO-LUMO gaps are computed for both species.

Table 5. Relevant Computed Data for $\left[\mathrm{Au}_{9} \mathrm{~L}_{8}\right]^{3+}$ Clusters $\left(\mathrm{L}=\mathbf{P P h}_{3}\left(\mathrm{Au}_{9}-\mathrm{P}\right)\right.$ and $\mathrm{L}=\mathrm{NHC}$, $\left(\mathrm{Au}_{9}-\mathrm{C}\right)$ ). Experimental Interatomic Distances of Aug-P Are Provided for Comparison. $\mathrm{Au}_{\mathrm{c}}$ and $\mathrm{Au}_{\mathrm{p}}$ Designate the Unique Central and the Eight Peripheral Atoms, Respectively

\begin{tabular}{|c|c|c|c|c|}
\hline & $\mathbf{A} \mathbf{u}_{9}-\mathbf{P} \exp ^{47}\left(D_{2}\right)$ & $\mathbf{A u _ { 9 } - \mathbf { P } ( D _ { 2 } )}$ & $\mathbf{A} \mathbf{u}_{9}-\mathbf{C}\left(D_{2}\right)$ \\
\hline \multirow{3}{*}{$\begin{array}{c}\text { Distance }(\AA) \\
\text { [WBI] }\end{array}$} & $\mathrm{Au}_{\mathrm{c}}-\mathrm{Au}_{\mathrm{p}}$ & av. 2.692 & av. $2.717[0.132]$ & av. $2.729[0.144]$ \\
\hline & $\mathrm{Au}_{\mathrm{p}}-\mathrm{Au}_{\mathrm{p}}$ & av. 2.834 & av. $2.842[0.096]$ & av. 2.888 [0.099] \\
\hline & $\mathrm{Au}-\mathrm{L}$ & av. 2.281 & av. $2.294[0.441]$ & av. $2.043[0.460]$ \\
\hline \multicolumn{2}{|c|}{ HOMO-LUMO gap (eV) } & & 1.54 & 1.50 \\
\hline \multirow{3}{*}{$\begin{array}{c}\text { NAO charge } \\
\text { (av.) }\end{array}$} & $\overline{\mathrm{Au}_{\mathrm{c}}}$ & & -0.05 & -0.05 \\
\hline & $\mathrm{Au}_{\mathrm{p}}$ & & +0.08 & +0.16 \\
\hline & $\mathrm{L}$ & & +0.30 & +0.22 \\
\hline
\end{tabular}

The 8-electron $\mathbf{A} \mathbf{u}_{11}-\mathbf{P}$ cluster (Figure 1) can be viewed as resulting from the bridging of the $\mathbf{A u}_{9}$-P metal core on two opposite sides (along the $y$ axis) by two supplementary $\mathrm{Au}\left(\mathrm{PPh}_{3}\right)_{2}$ units. It has two more electrons than $\mathbf{A u}_{\mathbf{g}}-\mathbf{P}$ that are located in a kind of $1 \mathrm{D}_{\mathrm{y}}{ }^{2} \mathrm{HOMO}$, resulting in the prolate $1 \mathrm{~S}^{2} 1 \mathrm{P}^{4} 1 \mathrm{D}^{2}$ closed-shell configuration. Its LUMO can be tentatively described as a 
2P $\mathrm{P}_{\mathrm{y}}$ level (Figure S7). Au $\mathbf{u}_{11} \mathbf{- C}$ has comparable geometry (Table 6) and electronic structure (Figure S8).

Table 6. Relevant Computed Data for $\left[\mathrm{Au}_{11} \mathrm{~L}_{6}\right]^{3+}$ Clusters $\left(\mathrm{L}=\mathrm{dppe}\left(\mathrm{Au}_{11}-\mathrm{P}\right)\right.$ and $\mathrm{L}=\mathrm{di}-$ NHC'e $\left.\left(\mathrm{Au}_{11}-\mathrm{C}\right)\right)$. Experimental Interatomic Distances of $\mathrm{Au}_{11}-\mathrm{P}$ Are Provided for Comparison. $\mathrm{Au}_{\mathrm{c}}, \mathrm{Au}_{\mathrm{p}}$ and $\mathrm{Au}_{\mathrm{b}}$ Designate the Unique Central, the Eight Peripheral Atoms and the Two Bridging Atoms, Respectively

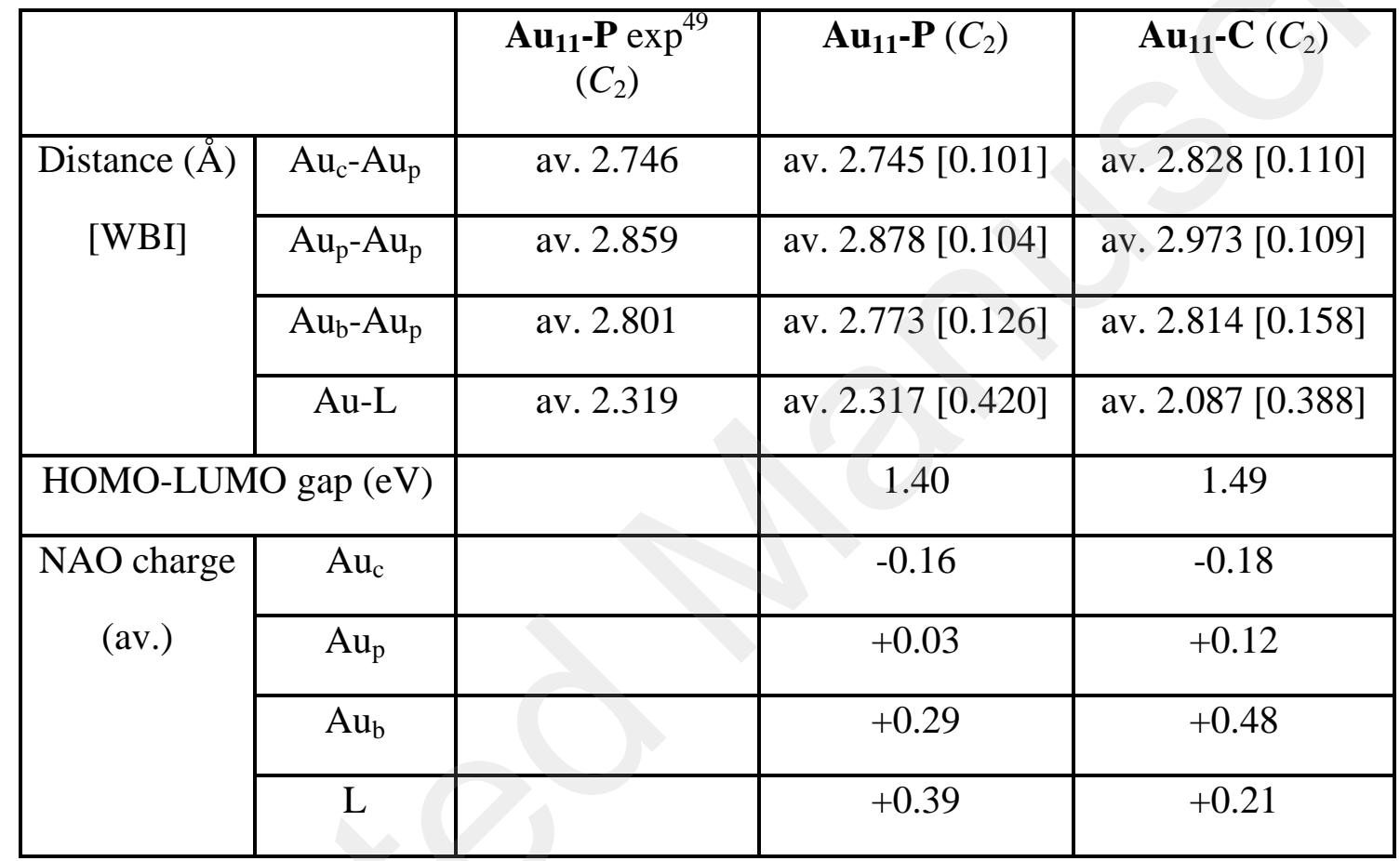

Finally, the last three phosphine clusters of the series (Table 1), namely $\mathbf{A u}_{1 \mathbf{1 1}} \mathbf{C l}_{\mathbf{2}}-\mathbf{P}, \mathbf{A u}_{\mathbf{1 3}} \mathbf{C l}_{\mathbf{2}} \mathbf{-} \mathbf{P}$ (already theoretically studied previously) ${ }^{71}$ and $\mathbf{A u}_{13} \mathbf{C l}_{3}-\mathbf{P}$ (Figure 1), are more compact, exhibiting a centered icosahedral core (incomplete in the case of $\mathbf{A u}_{11} \mathbf{C l}_{\mathbf{2}}-\mathbf{P}$ ). The somewhat distorted icosahedra display rather homogeneous $\mathrm{Au}_{\mathrm{c}}-\mathrm{Au}_{\mathrm{p}}$ distances (Table 7). They are all regular 8-electron pseudo-spherical superatoms with $1 \mathrm{~S}^{2} 1 \mathrm{P}^{6}$ configuration. The HOMOs and LUMOs are of 1P and 1D nature, respectively (Figure S7). Their NHC counterparts, $\mathbf{A u}_{\mathbf{1 1}} \mathbf{C l}_{\mathbf{2}} \mathbf{-} \mathbf{C}$, $\mathbf{A u}_{13} \mathbf{C l}_{2}-\mathbf{C}$, and $\mathbf{A u}_{13} \mathbf{C l}_{3}-\mathbf{C}$ exhibit quite similar features (Table 7 and Figure S8). 
Hence, besides the already characterized NHC-protected as protecting ligands for $\mathrm{Au}_{6}$ and $\mathrm{Au}_{13}$ clusters, ${ }^{32,33}$ carbene ligands appear to be able to stabilize gold clusters of any size. Thus, size-dependent properties related to cluster core nuclearity can be explored, in addition to the versatility shown by NHC's characteristics ranging from strong to weak donor ligands. ${ }^{40}$ 
Table 7. Relevant Computed Data for $\left[\mathrm{Au}_{11} \mathrm{Cl}_{2} \mathrm{~L}_{8}\right]^{+}$Clusters $\left(\mathrm{L}=\mathrm{PPh}_{3}\left(\mathrm{Au}_{11} \mathrm{Cl}_{2}-\mathrm{P}\right)\right.$ and $\left.\mathrm{L}=\mathrm{NHC}^{\prime}\left(\mathrm{Au}_{11} \mathrm{Cl}_{2}-\mathrm{C}\right)\right)$; $\left[\mathrm{Au}_{13} \mathrm{Cl}_{2} \mathrm{~L}_{5}\right]^{3+}$ Clusters $\left(\mathrm{L}=\right.$ dppe $\left(\mathrm{Au}_{13} \mathrm{Cl}_{2}-\mathrm{P}\right)$ and $\mathrm{L}=\operatorname{di}-\mathrm{NHC}$ 'e $\left.\left(\mathrm{Au}_{13} \mathrm{Cl}_{2}-\mathrm{C}\right)\right)$; $\left[\mathrm{Au}_{13} \mathrm{Cl}_{3} \mathrm{~L}_{9}\right]^{2+}$ Clusters $\left(\mathrm{L}=\mathrm{PPh}_{3}\left(\mathrm{Au}_{13} \mathrm{Cl}_{3}-\mathrm{P}\right)\right.$ and $\mathrm{L}=\mathrm{NHC}$ ' $\left(\mathrm{Au}_{13} \mathrm{Cl}_{3}-\mathrm{C}\right)$ ). Experimental Interatomic Distances Are Provided for Comparison. Au $\mathrm{u}_{\mathrm{c}}$ and Au Designate the Central and Peripheral Atoms, Respectively

\begin{tabular}{|c|c|c|c|c|c|c|c|c|c|c|}
\hline & & \multicolumn{3}{|c|}{$\mathbf{A} \mathbf{u}_{11} \mathbf{C l}_{2}-\mathbf{X}\left(C_{1}\right)$} & \multicolumn{3}{|c|}{$\mathbf{A u}_{13} \mathbf{C l}_{2}-\mathbf{X}\left(C_{1}\right)$} & \multicolumn{3}{|c|}{$\mathbf{A} \mathbf{u}_{13} \mathbf{C l}_{3}-\mathbf{X}\left(C_{1}\right)$} \\
\hline & & $\begin{array}{l}\mathrm{Au}_{11} \mathbf{C l}_{2}-\mathbf{P} \\
\exp ^{51}\end{array}$ & $\mathrm{Au}_{11} \mathrm{Cl}_{2}-\mathrm{P}$ & $\mathrm{Au}_{11} \mathrm{Cl}_{2}-\mathrm{C}$ & \begin{tabular}{|}
$\mathbf{A u}_{13} \mathbf{C l}_{\mathbf{2}}-\mathbf{P}$ \\
$\exp ^{52}$
\end{tabular} & $\mathrm{Au}_{13} \mathrm{Cl}_{2}-\mathrm{P}$ & $\mathrm{Au}_{13} \mathrm{Cl}_{2}-\mathrm{C}$ & $\begin{array}{c}\mathrm{Au}_{13} \mathrm{Cl}_{3}-\mathrm{C} \\
\exp ^{33}\end{array}$ & $\mathrm{Au}_{13} \mathrm{Cl}_{3}-\mathrm{P}$ & $\mathrm{Au}_{13} \mathrm{Cl}_{3}-\mathrm{C}$ \\
\hline \multirow{4}{*}{$\begin{array}{c}\text { Distance } \\
(\AA) \\
{[\mathrm{WBI}]}\end{array}$} & $A u_{c}-A u_{p}$ & av. 2.687 & $\begin{array}{c}\text { av. } 2.702 \\
{[0.140]}\end{array}$ & $\begin{array}{c}\text { av. } 2.718 \\
{[0.155]}\end{array}$ & av. 2.764 & $\begin{array}{c}\text { av. } 2.773 \\
{[0.121]}\end{array}$ & $\begin{array}{c}\text { av. 2.787 } \\
{[0.135]}\end{array}$ & av. 2.768 & $\begin{array}{c}\text { av. 2.801 } \\
{[0.119]}\end{array}$ & $\begin{array}{c}\text { av. } 2.800 \\
{[0.131]}\end{array}$ \\
\hline & $A u_{p}-A u_{p}$ & av. 2.954 & $\begin{array}{c}\text { av. } 2.877 \\
{[0.072]}\end{array}$ & $\begin{array}{c}\text { av. } 3.019 \\
{[0.069]}\end{array}$ & av. 2.906 & $\begin{array}{c}\text { av. 2.916 } \\
{[0.063]}\end{array}$ & $\begin{array}{c}\text { av. } 2.930 \\
{[0.063]}\end{array}$ & av. 2.911 & $\begin{array}{c}\text { av. } 2.946 \\
{[0.065]}\end{array}$ & $\begin{array}{c}\text { av. } 2.945 \\
{[0.066]}\end{array}$ \\
\hline & $\mathrm{Au}_{\mathrm{p}}-\mathrm{Cl}$ & av. 2.357 & $\begin{array}{l}\text { av. } 2.388 \\
{[0.322]}\end{array}$ & $\begin{array}{c}\text { av. } 2.422 \\
{[0.285]}\end{array}$ & av. 2.351 & $\begin{array}{c}\text { av. } 2.348 \\
{[0.381]}\end{array}$ & $\begin{array}{c}\text { av. } 2.355 \\
{[0.384]}\end{array}$ & av. 2.352 & $\begin{array}{c}\text { av. } 2.381 \\
{[0.324]}\end{array}$ & $\begin{array}{c}\text { av. } 2.394 \\
{[0.316]}\end{array}$ \\
\hline & $\mathrm{Au}-\mathrm{L}$ & av. 2.289 & $\begin{array}{c}\text { av. } 2.288 \\
{[0.411]} \\
\end{array}$ & $\begin{array}{c}\text { av. } 2.042 \\
{[0.429]}\end{array}$ & av. 2.289 & $\begin{array}{c}\text { av. } 2.289 \\
{[0.664]}\end{array}$ & $\begin{array}{c}\text { av. } 2.036 \\
{[0.448]} \\
\end{array}$ & av. 2.051 & $\begin{array}{c}\text { av. } 2.313 \\
{[0.440]}\end{array}$ & $\begin{array}{c}\text { av. } 2.047 \\
{[0.442]} \\
\end{array}$ \\
\hline \multicolumn{2}{|c|}{$\begin{array}{c}\text { HOMO-LUMO gap } \\
(\mathrm{eV})\end{array}$} & & 1.89 & 1.91 & & 1.74 & 2.02 & & 1.90 & 2.13 \\
\hline \multirow{4}{*}{$\begin{array}{l}\text { NAO } \\
\text { charge } \\
\text { (av.) }\end{array}$} & $\mathrm{Au}_{\mathrm{C}}$ & & -0.22 & -0.24 & & -0.32 & -0.33 & & -0.27 & -0.27 \\
\hline & $\mathrm{Au}_{\mathrm{p}}$ & & +0.10 & +0.16 & & +0.15 & +0.21 & & +0.15 & +0.21 \\
\hline & $\mathrm{Cl}$ & & -0.60 & -0.63 & & -0.55 & -0.57 & & -0.57 & -0.61 \\
\hline & $\mathrm{L}$ & & +0.17 & +0.12 & & +0.54 & +0.39 & & +0.24 & +0.17 \\
\hline
\end{tabular}




\subsection{Bonding Energies}

A more quantitative comparison of the thermodynamic stability of the investigated phosphine and NHC species can be performed from the comparison of the energies of interaction between the ligands and the metal core, but also from the evaluation of the energy cost associated with the distortion afforded by the metal core upon complexation. To this end, we optimized the geometries of the bare $\left[\mathrm{Au}_{n}\right]^{\mathrm{x}+}$ core of the investigated species, obtained after removal of the neutral phosphine (or NHC) and anionic chloride (if any) ligands. Interestingly, these optimized bare ionic metal cores maintain the structure that they adopt in the $\mathbf{A} \mathbf{u}_{\mathbf{n}}-\mathbf{P}, \mathbf{A u}_{\mathbf{n}} \mathbf{C l} \mathbf{l}_{\mathbf{m}}-\mathbf{P}$ experimental structures (see Figure S17). Apart from the icosahedral $\left[\mathrm{Au}_{13}\right]^{5+}$ core, ${ }^{72}$ there is no certainty that such configurations are global minima, ${ }^{73}$ but at least they are local minima, as ascertained by vibrational frequency analyses. Consistently, they all present a significant HOMO-LUMO gap (> $1 \mathrm{eV})$, except that of $\left[\mathrm{Au}_{8}\right]^{2+}(0.39 \mathrm{eV})$, perhaps due to its low compacity. Interestingly, the two optimized $\left[\mathrm{Au}_{11}\right]^{3+}$ structures differ by a substantial energy difference of $1.07 \mathrm{eV}$ at the expense of the less compact one. The energy cost afforded by the bare metal cores to prepare their structure to bonding with ligands $\left(E_{\text {Prep }}\right)$ is given in Table 8. It is computed as the difference between the energy of the $\left[\mathrm{Au}_{\mathrm{n}}\right]^{\mathrm{X}}$ core as it is in the optimized $\mathbf{A} \mathbf{u}_{\mathbf{n}}-\mathbf{X}$ or $\mathbf{A} \mathbf{u}_{\mathbf{n}} \mathbf{C} \mathbf{l}_{\mathbf{x}}-\mathbf{X}$ species and that of the free $\left[\mathrm{Au}_{n}\right]^{\mathrm{X}}$. Most of these values are small, consistently with the moderate change of the metal configuration upon complexation. The exception of $\mathbf{A u}_{6}-\mathbf{C}$ can be explained by its structural difference with its $\mathbf{A u}_{6}-\mathbf{P}$ counterpart (see above). That of the two $\left[\mathrm{Au}_{11}\right]^{3+}$ cores constitute also an exception, but they show similar $E_{\text {Prep }}$ values for both phosphine and NHC clusters. Thus, except for the $\mathbf{A u}_{6}-\mathbf{X}(\mathbf{X}=\mathbf{P}, \mathbf{C})$ clusters, the $E_{\text {Prep. }}$ values of the phosphine and NHC couples are very similar. 
Table 8. Energetic Data Associated with Cluster Bonding (all Values in eV). $E_{\text {Prep. }}=$ Energy Cost Afforded by the Bare $\left[\mathrm{Au}_{\mathrm{n}}\right]^{\mathrm{x}+}$ Metal Core to Go From its Equilibrium Structure to That It Adopts in the $\mathrm{Au}_{\mathrm{n}}-\mathrm{X}$ or $\mathrm{Au}_{\mathrm{n}} \mathrm{Cl}_{\mathrm{m}}-\mathrm{X}$ Cluster. $E_{\text {bond. }}=E\left(A u_{n}-X\right)-E\left(\left[A u_{n}\right]^{X+}\right)-E(n e u t r a l$ ligand sphere) or $E_{\text {bond. }}=E\left(A u_{n} C l_{m}-X\right)-E\left(\left[A u_{n} C l_{m} l^{(x-m)+}\right)-E(N e u t r a l\right.$ Ligand Sphere $)$.

\begin{tabular}{|c|c|c|c|c|c|}
\hline Compound & $\begin{array}{c}\text { Corresponding } \\
\text { optimized metal core }^{\mathrm{a}}\end{array}$ & $\begin{array}{c}\mathbf{X}=\mathbf{P} \\
E_{\text {Prep. }}(\text { metal core })\end{array}$ & $\begin{array}{c}\mathbf{X}=\mathbf{C} \\
E_{\text {Prep. }}(\text { metal core })\end{array}$ & $\begin{array}{l}\mathbf{X}=\mathbf{P} \\
E_{\text {Bond. }}\end{array}$ & $\begin{array}{l}\mathbf{X}=\mathbf{C} \\
E_{\text {Bond. }}\end{array}$ \\
\hline $\mathrm{Au}_{6}-\mathrm{X}$ & {$\left[\mathrm{Au}_{6}\right]^{2+}\left(D_{2}\right)$} & 0.19 & 2.85 & -24.97 & -29.25 \\
\hline $\mathbf{A u} u_{8}-\mathrm{X}$ & {$\left[\mathrm{Au}_{8}\right]^{2+}\left(C_{2}\right)$} & 0.38 & 0.32 & -26.88 & -28.70 \\
\hline $\mathrm{Au}_{8} \mathrm{Cl}_{2}-\mathrm{X}$ & {$\left[\mathrm{Au}_{8}\right]^{4+}\left(D_{2 h}\right)$} & 0.21 & 0.23 & -29.59 & -31.36 \\
\hline $\mathbf{A u _ { 9 } - X}$ & {$\left[\mathrm{Au}_{9}\right]^{3+}\left(D_{2 h}\right)$} & 0.09 & 0.15 & -33.78 & -35.86 \\
\hline $\mathrm{Au}_{11}-\mathrm{X}$ & {$\left[\mathrm{Au}_{11}\right]^{3+}\left(C_{2}, \Delta \mathrm{E}=1.07^{\mathrm{b}}\right)$} & 1.09 & 1.24 & -39.68 & -41.53 \\
\hline $\mathrm{Au}_{11} \mathrm{Cl}_{2}-\mathrm{X}$ & {$\left[\mathrm{Au}_{11}\right]^{3+}\left(C_{2}, \Delta \mathrm{E}=0.00^{\mathrm{b}}\right)$} & 1.02 & 1.00 & -25.01 & -27.23 \\
\hline $\mathrm{Au}_{13} \mathrm{Cl}_{2}-\mathrm{X}$ & \multirow{2}{*}[\mathrm{Au}_{13}]{$^{5+}\left(I_{h}\right)$} & 0.49 & 0.40 & -40.04 & -42.58 \\
\hline $\mathrm{Au}_{13} \mathrm{Cl}_{3}-\mathrm{X}$ & & 0.38 & 0.33 & -33.67 & -37.32 \\
\hline
\end{tabular}

Neutral Ligands $=$ Phosphines or NHCs. All Fragment Structures Taken From the $\mathrm{Au}_{\mathrm{n}}-\mathrm{X}$ or $\mathrm{Au}_{\mathbf{n}} \mathrm{Cl}_{\mathrm{m}}-\mathrm{X}$ Optimized Geometries

${ }^{\mathrm{a}}$ See Figure S17.

${ }^{\mathrm{b}}$ Relative energies between $\left[\mathrm{Au}_{11}\right]^{3+}$ isomers.

The bonding energy ( $E_{\text {Bond. }}$ ) of the neutral phosphine or NHC ligand sphere to the $\left[\mathrm{Au}_{n}\right]^{\mathrm{x}}$ or $\left.\left[\mathrm{Au}_{\mathrm{n}} \mathrm{Cl}\right]_{\mathrm{m}}\right]^{(\mathrm{x}-\mathrm{m})+}$ fragments in the $\mathbf{A} \mathbf{u}_{\mathbf{n}}-\mathbf{X}$ or $\mathbf{A} \mathbf{u}_{\mathbf{n}} \mathbf{C} \mathbf{I}_{\mathbf{m}}-\mathbf{X}$, respectively, was computed according to

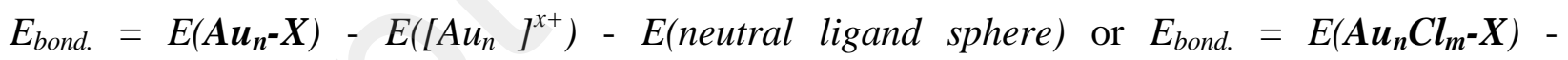
$E\left(\left[A u_{n} C l_{m}\right]^{(x-m)+}\right)-E($ neutral ligand sphere $)$, respectively. In these equations, all the considered (frozen) fragment structures were taken from the $\mathbf{A} \mathbf{u}_{\mathbf{n}}-\mathbf{X}$ or $\mathbf{A} \mathbf{u}_{\mathbf{n}} \mathbf{C l}_{\mathbf{m}}-\mathbf{X}$ optimized geometries. It is clear from Table 8 that the NHCs are more strongly bonded than their phosphine analogues in all the investigated systems. The difference is not very large, but significant (a few eVs). Even taking into account the $E_{\text {Prep. }}$ destabilizing component, the difference remains in favor of stronger NHC bonding. When this difference is normalized to one phosphine/carbene function, it is found 


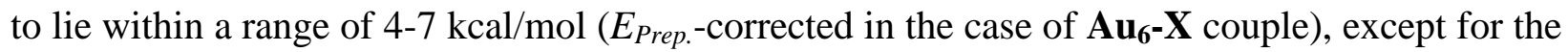
$\mathbf{A u}_{13} \mathbf{C l}_{3}-\mathbf{X}$ system where it is a bit higher $(10 \mathrm{kcal} / \mathrm{mol})$.

\subsection{Optical properties}

The UV-Vis absorption spectra of the computed clusters were simulated (see Computational Details above). They are gathered in Figure 3 and the major computed electronic transition energies associated with are given in Table 9, together with corresponding experimental $\lambda_{\max }$ values taken from the literature where available. ${ }^{33,44-53}$ Although spin orbit corrections were not considered in our calculations, a good match was obtained between the computed excitation energies and the available experimental $\lambda_{\max }$ values, in particular for the low-energy transitions. This agreement provides confidence in the reliability of our results, retaining small deviations (0.07 to $0.32 \mathrm{eV}$ ) within the method error. ${ }^{19}$ Going from $\mathrm{L}=$ phosphine to $\mathrm{L}=$ NHC does not change importantly the nature and the energies of the optical transitions of a given cluster and consequently the shape of its simulated spectrum. A general blue-shift tendency is observed when going from $\mathrm{L}$ = phosphine to $\mathrm{L}=$ NHC, except for the low-energy absorption band of $\mathbf{A u}_{\mathbf{9}}$ $\mathbf{X}$ (Figure 3) in agreement with the smaller HOMO-LUMO gaps computed for the later over all. Indeed, in the $\mathbf{A} \mathbf{u}_{6}-\mathbf{P}$ to $\mathbf{A} \mathbf{u}_{11}-\mathbf{P}$ series, the lowest energy band is associated with a HOMO $\rightarrow$ LUMO transition of metal-to-metal charge transfer (MMCT) nature (Table 9). A transition involving orbitals of the same nature is found for the homologous $\mathbf{A} \mathbf{u}_{6}-\mathbf{C}$ to $\mathbf{A} \mathbf{u}_{11}-\mathbf{C}$ series, although in the cases of $\mathbf{A u}_{6} \mathbf{-} \mathbf{C}$ and $\mathbf{A} \mathbf{u}_{9}-\mathbf{C}$ it is a HOMO $\rightarrow$ LUMO+2 transition, which is mainly responsible. In the pseudo-spherical $\mathbf{A u}_{11} \mathbf{C l}_{2}-\mathbf{X}$ to $\mathbf{A u}_{13} \mathbf{C l}_{3}-\mathbf{X}(\mathrm{X}=\mathrm{P}, \mathrm{C})$ series, the lowenergy band is associated to MMCT $1 \mathrm{P} \rightarrow 1 \mathrm{D}$ transitions.

In the two $\mathbf{A u}_{\mathbf{6}}-\mathbf{X}$ and $\mathbf{A} \mathbf{u}_{11}-\mathbf{X}(\mathrm{X}=\mathrm{P}, \mathrm{C})$ series the major transitions of higher energy are mainly of $5 d(A u) \rightarrow$ ligand character, sometimes mixed with some $5 d(A u) \rightarrow 6 s / 6 p(A u)$ character. 
In the pseudo-spherical $\mathbf{A u}_{11} \mathbf{C l}_{2}-\mathbf{X}$ and $\mathbf{A u}_{13} \mathbf{C l}_{3}-\mathbf{X}(\mathrm{X}=\mathrm{P}, \mathrm{C})$ series, the high-energy transitions are mainly of $5 \mathrm{~d}(\mathrm{Au}) \rightarrow 1 \mathrm{D}$ character. Note that similar results were theoretically obtained for $\mathrm{Au}_{13} \mathrm{Cl}_{2}-\mathbf{P}{ }^{71}$

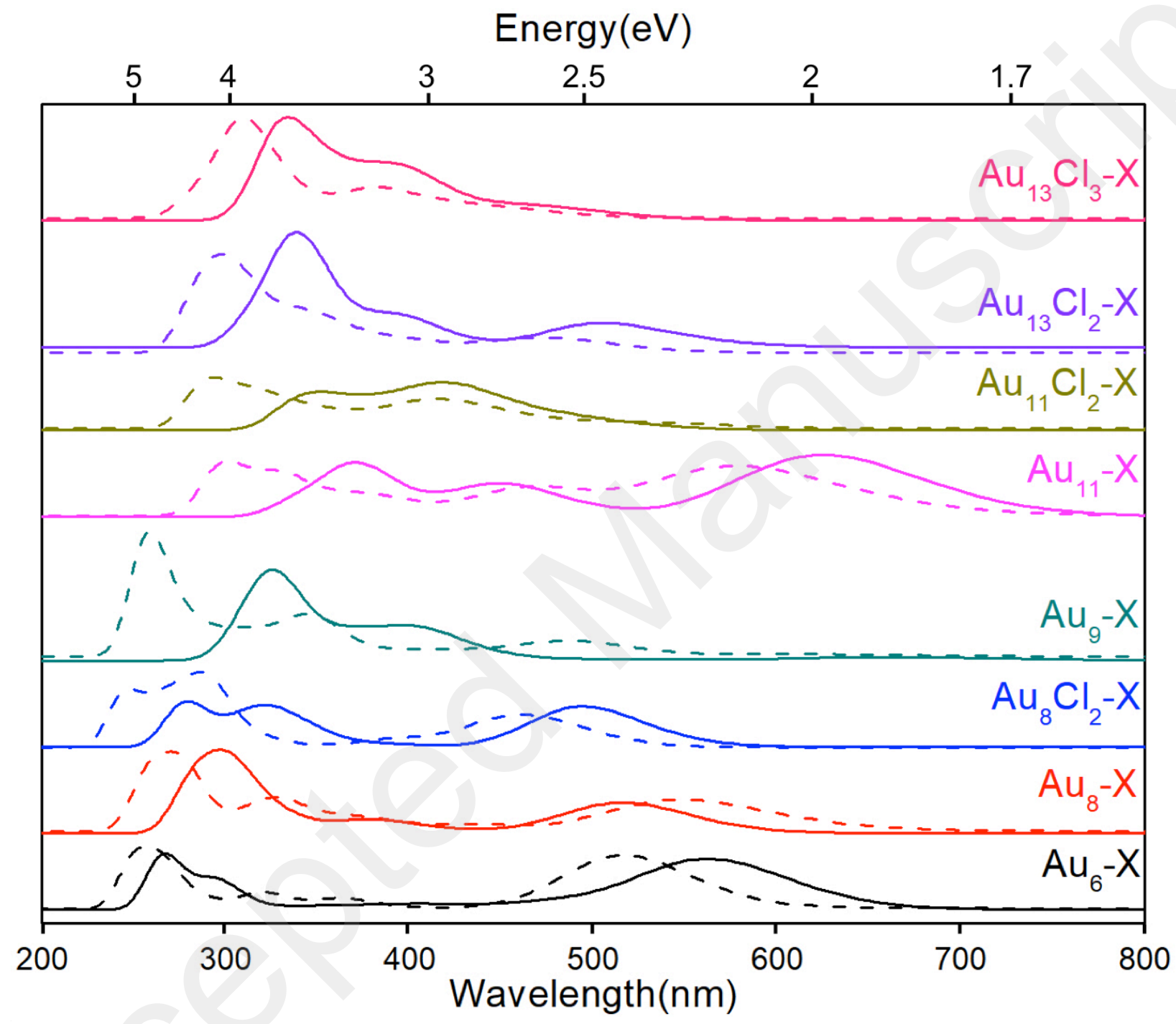

Figure 3. Simulated UV-Vis absorption spectra for computed $\mathbf{A} \mathbf{u}_{\mathbf{n}}-\mathbf{P}$ (solid line) and $\mathbf{A} \mathbf{u}_{\mathbf{n}}-\mathbf{C}$ (dotted line) clusters. 
Table 9. Major TD-DFT-Computed UV-Vis Excitation Energies. Bold Values Are Associated With the More Intense Absorption Bands in the Simulated Spectra Shown in Figure 3. Available Experimental $\lambda_{\max }$ Values Are Reported for Comparison

\begin{tabular}{|c|c|c|c|c|}
\hline \multirow{2}{*}{ Compound } & \multicolumn{3}{|c|}{ Absorption $\lambda(\mathrm{nm})$} & \multirow{2}{*}{$\begin{array}{l}\text { Major character of } \\
\text { the low-energy band } \\
\qquad(\mathrm{X}=\mathrm{P}, \mathrm{C})\end{array}$} \\
\hline & Exp. $^{a}$ & $\mathrm{X}=\mathrm{P}$ & $\mathrm{X}=\mathrm{C}$ & \\
\hline$A u_{6}-X$ & $587,432,326^{45}$ & $\begin{array}{c}564,417,299, \\
272\end{array}$ & $\begin{array}{c}\text { 517, 363, 321, } \\
262\end{array}$ & $\mathrm{Au}_{\mathrm{t}} \rightarrow \mathrm{Au}_{\mathrm{b}}$ \\
\hline $\mathrm{Au}_{8}-\mathrm{X}$ & 590 (sh), 520, $308^{46}$ & 516, 390, 304 & 538, 322, 277 & $\mathrm{Au}_{\text {outer }} \rightarrow \mathrm{Au}_{\text {center }}$ \\
\hline $\mathrm{Au}_{8} \mathrm{Cl}_{2}-\mathrm{X}$ & $508,390,322^{46}$ & 494, 327, 281 & $460,298,277$ & $\mathrm{Au}_{\mathrm{m}+\mathrm{s}} \rightarrow \mathrm{Au}_{\mathrm{b}}$ \\
\hline$A u_{9}-X$ & $\begin{array}{c}443,375 \text { (Sh), } 352 \text { (sh), } \\
314^{47}\end{array}$ & 404, 332 & 488, 347, 262 & $1 \mathrm{P}_{\mathrm{x}} \rightarrow 1 \mathrm{D}_{\mathrm{x} 2-\mathrm{y} 2}$ \\
\hline $\mathrm{Au}_{11}-\mathrm{X}$ & 663,471 (sh), 390, $316^{49}$ & $625,445,370$ & $573,472,326$ & $1 \mathrm{D}_{\mathrm{y} 2} \rightarrow 2 \mathrm{P}_{\mathrm{y}}$ \\
\hline $\mathrm{Au}_{11} \mathrm{Cl}_{2}-\mathrm{X}$ & $416,312,240^{51}$ & 426,353 & 416,298 & $1 \mathrm{P} \rightarrow 1 \mathrm{D}$ \\
\hline $\mathrm{Au}_{13} \mathrm{Cl}_{2}-\mathrm{X}$ & 493, 359, $304(\mathrm{sh})^{52}$ & 505, 390, 340 & $\begin{array}{c}\text { 470, 408, 354, } \\
307\end{array}$ & $1 \mathrm{P} \rightarrow 1 \mathrm{D}$ \\
\hline $\mathrm{Au}_{13} \mathrm{Cl}_{3}-\mathrm{X}$ & $490,420,330^{33}$ & 466, 391, 329 & 434, 376, 304 & $1 \mathrm{P} \rightarrow 1 \mathrm{D}$ \\
\hline
\end{tabular}

${ }^{a} \mathrm{X}=\mathrm{P}$ except for $\mathrm{Au}_{13} \mathrm{Cl}_{3}-\mathrm{X}$, for which $\mathrm{X}=\mathrm{C} .{ }^{33}$

In order to get an idea of the emission wavelength change when going from phosphine- to NHC-protected species, we have computed the corresponding transitions assuming both fluorescence and phosphorescence behavior. The emission energies were calculated by TD-DFT as vertical transitions between the optimized singlet excited state and the ground state (see Computational Details). They are given in Table 10, together with the experimental data available for the $\mathbf{A} \mathbf{u}_{\mathbf{n}}-\mathbf{P}$ series ${ }^{46,47,52,53}$ and $\mathbf{A u}_{\mathbf{1 3}} \mathbf{C l}_{\mathbf{3}}-\mathbf{C}$. ${ }^{33}$ A reasonably good agreement is found between the experimental and TD-DFT values, giving us confidence in the computed data. When comparing the two $\mathbf{A} \mathbf{u}_{\mathbf{n}}-\mathbf{P}$ and $\mathbf{A} \mathbf{u}_{\mathbf{n}}-\mathbf{C}$ series, similar values are obtained, except for the $\mathbf{A} \mathbf{u}_{\mathbf{6}}-\mathbf{X}$ homologues for which the large difference in their emission wavelength can be related to the 
significant difference in their structure (see below). In any case, no systematic tendency (blue- or red-shifting) is found when going from $\mathbf{A} \mathbf{u}_{\mathbf{n}}-\mathbf{P}$ to $\mathbf{A u}_{\mathbf{n}} \mathbf{-} \mathbf{C}$, which is attributable to size-dependent and core-composition effects exhibited by the respective cluster core along the series.

Table 10. TD-DFT computed hypothetical fluorescence emission energies.

\begin{tabular}{|c|c|c|c|}
\hline Compound & $\overline{E_{\text {emission }}}$ & Compound & $E_{\text {emission }}$ \\
\hline $\mathrm{Au}_{6}-\mathrm{P}$ & $2.24 \mathrm{eV}(552 \mathrm{~nm})$ & $\mathrm{Au}_{6}-\mathrm{C}$ & 1.25 eV (992 nm) \\
\hline $\mathrm{Au}_{8}-\mathrm{P}$ & $\begin{array}{l}1.81 \text { eV }(683 \mathrm{~nm}) \\
\text { Non-luminescent }^{53}\end{array}$ & $\mathrm{Au}_{8}-\mathrm{C}$ & $1.75 \mathrm{eV}(707 \mathrm{~nm})$ \\
\hline $\mathrm{Au}_{8} \mathrm{Cl}_{2}-\mathrm{P}$ & $\begin{array}{c}2.08 \mathrm{eV}(595 \mathrm{~nm}) \\
\text { Exp. } 2.07 \mathrm{eV}(597 \mathrm{~nm})^{46}\end{array}$ & $\mathrm{Au}_{8} \mathrm{Cl}_{2}-\mathrm{C}$ & $2.62 \mathrm{eV}(473 \mathrm{~nm})$ \\
\hline $\mathrm{Au}_{9}-\mathrm{P}$ & $\begin{array}{c}1.39 \mathrm{eV}(891 \mathrm{~nm}) \\
\text { Exp. } 2.14 \mathrm{eV}, 1.45 \mathrm{eV} \\
(579 \mathrm{~nm}, 853 \mathrm{~nm})^{47}\end{array}$ & $\mathrm{Au}_{9}-\mathrm{C}$ & $1.52 \mathrm{eV}(814 \mathrm{~nm})$ \\
\hline $\mathrm{Au}_{11}-\mathrm{P}$ & $1.85 \mathrm{eV}(670 \mathrm{~nm})$ & $\mathrm{Au}_{11}-\mathrm{C}$ & $1.82 \mathrm{eV}(683 \mathrm{~nm})$ \\
\hline $\mathrm{Au}_{11} \mathrm{Cl}_{2}-\mathrm{P}$ & $\begin{array}{l}1.62 \mathrm{eV}(764 \mathrm{~nm}) \\
\text { Non-luminescent }^{53}\end{array}$ & $\mathrm{Au}_{11} \mathrm{Cl}_{2}-\mathrm{C}$ & $1.86 \mathrm{eV}(667 \mathrm{~nm})$ \\
\hline $\mathrm{Au}_{13} \mathrm{Cl}_{2}-\mathrm{P}$ & $\begin{array}{c}1.75 \mathrm{eV}(709 \mathrm{~nm}) \\
\text { Exp. } 1.62 \mathrm{eV}(766 \mathrm{~nm})^{52}\end{array}$ & $\mathrm{Au}_{13} \mathrm{Cl}_{2}-\mathrm{C}$ & $1.72 \mathrm{eV}(720 \mathrm{~nm})$ \\
\hline $\mathrm{Au}_{13} \mathrm{Cl}_{3}-\mathrm{P}$ & $1.76 \mathrm{eV}(705 \mathrm{~nm})$ & $\mathrm{Au}_{13} \mathrm{Cl}_{3}-\mathrm{C}$ & $\begin{array}{c}1.71 \mathrm{eV}(723 \mathrm{~nm}) \\
\text { Exp. } 1.59-1.70 \mathrm{eV} \\
(730-780 \mathrm{~nm})^{33}\end{array}$ \\
\hline
\end{tabular}

The phosphorescence emission energies were computed as vertical transitions between the triplet state in its equilibrium geometry and the singlet state in the same geometry. The results are given in Table 11. To our knowledge, no experimental evidence of phosphorescence has been reported for the known compounds. As in the case of fluorescence, the results do not show any 
general trend when going from phosphine- to NHC-protected clusters. Most of the computed transition energies are within the near-IR and IR range, which probably explains why phosphorescence is disfavored with respect to thermal relaxation, with perhaps the exception of $\mathrm{Au}_{13} \mathrm{Cl}_{2}-\mathrm{X}, \mathrm{Au}_{13} \mathrm{Cl}_{3}-\mathrm{X}$ and $\mathrm{Au}_{8} \mathrm{Cl}_{2}-\mathrm{X}(\mathrm{X}=\mathrm{P}, \mathrm{C})$.

Table 11. DFT-Computed Hypothetical Phosphorescence Emission

\begin{tabular}{|c|c|c|c|}
\hline Compound & $E_{\text {emission }}$ & Compound & $E_{\text {emission }}$ \\
\hline $\mathrm{Au}_{6}-\mathrm{P}$ & $1.46 \mathrm{eV}(849 \mathrm{~nm})$ & $\mathrm{Au}_{6}-\mathrm{C}$ & $1.13 \mathrm{eV}(1097 \mathrm{~nm})$ \\
\hline $\mathrm{Au}_{8}-\mathrm{P}$ & $0.68 \mathrm{eV}(1823 \mathrm{~nm})$ & $\mathrm{Au}_{8}-\mathrm{C}$ & $0.85 \mathrm{eV}(1458 \mathrm{~nm})$ \\
\hline $\mathrm{Au}_{8} \mathrm{Cl}_{2}-\mathrm{P}$ & $1.70 \mathrm{eV}(729 \mathrm{~nm})$ & $\mathrm{Au}_{8} \mathrm{Cl}_{2}-\mathrm{C}$ & $1.82 \mathrm{eV}(681 \mathrm{~nm})$ \\
\hline $\mathrm{Au}_{9}-\mathrm{P}$ & $1.09 \mathrm{eV}(1137 \mathrm{~nm})$ & $\mathrm{Au}_{9}-\mathrm{C}$ & $0.40 \mathrm{eV}(3099 \mathrm{~nm})$ \\
\hline $\mathrm{Au}_{11}-\mathrm{P}$ & $1.37 \mathrm{eV}(904 \mathrm{~nm})$ & $\mathrm{Au}_{11}-\mathrm{C}$ & $1.02 \mathrm{eV}(1215 \mathrm{~nm})$ \\
\hline $\mathrm{Au}_{11} \mathrm{Cl}_{2}-\mathrm{P}$ & $1.01 \mathrm{eV}(1227 \mathrm{~nm})$ & $\mathrm{Au}_{11} \mathrm{Cl}_{2}-\mathrm{C}$ & $0.81 \mathrm{eV}(1530 \mathrm{~nm})$ \\
\hline $\mathrm{Au}_{13} \mathrm{Cl}_{2}-\mathrm{P}$ & $1.40 \mathrm{eV}(885 \mathrm{~nm})$ & $\mathrm{Au}_{13} \mathrm{Cl}_{2}-\mathrm{C}$ & $1.41 \mathrm{eV}(879 \mathrm{~nm})$ \\
\hline $\mathrm{Au}_{13} \mathrm{Cl}_{3}-\mathrm{P}$ & $1.45 \mathrm{eV}(855 \mathrm{~nm})$ & $\mathrm{Au}_{13} \mathrm{Cl}_{3}-\mathrm{C}$ & $1.50 \mathrm{eV}(826 \mathrm{~nm})$ \\
\hline
\end{tabular}

Going from $\mathbf{A u}_{6}-\mathbf{P}$ to $\mathbf{A u}_{6}-\mathbf{C}$, a red shift in the fluorescence emission wavelength is found, which is also observed to a lesser extend in the $\mathbf{A u}_{\mathbf{8}} \mathbf{-} \mathbf{P} / \mathbf{A u}_{\mathbf{8}} \mathbf{-} \mathbf{C}$ counterparts. Interestingly, a blue shift is found in the case of the chlorine-derivatives $\mathbf{A u}_{\mathbf{8}} \mathbf{C l}_{\mathbf{2}}-\mathbf{P} / \mathbf{A u}_{\mathbf{8}} \mathbf{C l} \mathbf{l}_{2}-\mathbf{C}$, which is also observed for the $\mathbf{A u}_{11}-\mathbf{P} / \mathbf{A} \mathbf{u}_{11}-\mathbf{C}$ and $\mathbf{A u}_{11} \mathbf{C l}_{2}-\mathbf{P} / \mathbf{A u}_{11} \mathbf{C l}_{2}-\mathbf{C}$ pairs. A blue shift in the emission is also calculated for the $\mathbf{A} \mathbf{u}_{9}-\mathbf{P} / \mathbf{A u}_{9}-\mathbf{C}$ pair, depicting strong differences with the $\mathbf{A} \mathbf{u}_{6}, \mathbf{A} \mathbf{u}_{\mathbf{8}}$, and $\mathbf{A} \mathbf{u}_{11}$ cores. Hence, different cluster cores retain different behavior when NHC's ligands are included, increasing the versatility of the properties. 
Finally, we would like to make some comments about the energy difference between the first excited singlet and triplet states (Table S1). These gaps range 1.9-3.3 eV and 0.7-1.8 eV for the $\mathbf{A} \mathbf{u}_{\mathbf{n}}-\mathbf{P}$ and $\mathbf{A} \mathbf{u}_{\mathbf{n}}-\mathbf{C}$ series, respectively. Although these values are not accurate due to the way they were calculated (see Computational Details), two general trends can be noted. The first one is that within each series, this gap increases with the nuclearity. The second one is that it is much larger for $\mathbf{A} \mathbf{u}_{\mathbf{n}} \mathbf{- P}$ than for their $\mathbf{A} \mathbf{u}_{\mathbf{n}}-\mathbf{C}$ counterparts, whatever $n$. The particularly large gap computed for the $\mathbf{A} \mathbf{u}_{\mathbf{n}}-\mathbf{P}$ derivatives disfavors the intersystem crossing, also in agreement with the non-observation of phosphorescence in this experimentally characterized series. From this point of view, the $\mathbf{A} \mathbf{u}_{\mathbf{n}}-\mathbf{C}$ series appears more capable for enabling intersystem crossing and possible phosphorescence.

\section{Conclusions}

The hypothetical NHC-protected gold clusters we have calculated exhibit similar structural chemistry as their experimentally characterized phosphine-protected analogs. The similarities in bond distances and Wiberg bond indices are indicative of analogous thermodynamic stability. This is confirmed by the evaluation of the gold-P and gold-C bonding energies in these species, the latter being even slightly stronger than the former by a few $\mathrm{kcal} / \mathrm{mol}$. This is in phase with what is known from the few NHC-protected gold clusters known so far. ${ }^{32-34,36}$ The comparable HOMO-LUMO gaps are also indicative of comparable kinetic stability. Their optical properties are also likely to be quite similar, the NHC derivatives being however more prone to exhibit phosphorescence behavior. Our results show the feasibility to achieve variable-sized stable NHC-protected gold clusters with properties related to their parent phosphine-protected species. This allows further evaluation of size-dependent properties, which in addition, takes advantage 
of the versatility in the electronic properties of the NHC's family, ranging from strong to weak donor ligands.

\section{ASSOCIATED CONTENT}

\section{Supporting Information.}

Details regarding the calculated density of states and MO diagrams for the cluster series

investigated by the paper, the plotted frontier orbitals, the computed energy difference between the first excited singlet and triplet states and structures of the investigated $\left[\mathrm{Au}_{n}\right]^{\mathrm{x}+}$ bare systems . (PDF).

\section{AUTHOR INFORMATION}

\section{Corresponding Authors}

Jean-Yves Saillard, Email: jean-yves.saillard@univ-rennes1.fr

Alvaro Muñoz-Castro, Email: alvaro.munoz@uautonoma.cl

\section{ORCID}

Jean-François Halet: 0000-0002-2315-4200

Jean-Yves Saillard: 0000-0003-4469-7922

Alvaro Muñoz-Castro: 0000-0001-5949-9449

\section{Notes}

The authors declare no conflict of interest. 


\section{DEDICATION}

This paper is dedicated to our colleague and friend Dr. Jean-René Hamon on the occasion of his 65th birthday.

\section{ACKNOWLEDGMENTS}

The authors are grateful to the Chilean-French ECOS-CONYCYT program (project C18E04) and to the French-Chilean International Associated Laboratory for "Multifunctional Molecules and Materials” (LIA-CNRS N¹027). The GENCI (Grand Equipment National de Calcul Intensif) is acknowledged for HCP support (project a0010807367). J. W. thanks the China Scholarship Council for a Ph.D. grant. A.M.-C. acknowledges support from Fondecyt 1180683. Dr. R. Marchal is acknowledged for technical support.

\section{REFERENCES}

(1) Qian, H.; Jin, R. Controlling nanoparticles with atomic precision: The case of $\mathrm{Au}_{144}\left(\mathrm{SCH}_{2} \mathrm{CH}_{2} \mathrm{Ph}\right)_{60}$. Nano Lett. 2009, 9, 4083-4087.

(2) Levi-Kalisman, Y.; Jadzinsky, P. D.; Kalisman, N.; Tsunoyama, H.; Tsukuda, T.; Bushnell, D. A.; Kornberg, R. D. Synthesis and characterization of $\mathrm{Au}_{102}(p-\mathrm{MBA})_{44}$ nanoparticles. J. Am. Chem. Soc. 2011, 133, 2976-2982.

(3) Qian, H.; Zhu, M.; Wu, Z.; Jin, R. Quantum sized gold nanoclusters with atomic precision. Acc. Chem. Res. 2012, 45, 1470-1479. 
(4) Tsukuda, T. Optical properties of ultra-small gold nanostructures. Springer Series in Chemical Physics (Progress in Photon Science). 2017, 115, 205-218.

(5) Kang, X.; Chong, H.; Zhu, M. $\mathrm{Au}_{25}(\mathrm{SR})_{18}$ : the captain of the great nanocluster ship. Nanoscale 2018, 10, 10758-10834.

(6) Tang, Q.; Hu, G.; Fung, V.; Jiang, D. Insights into interfaces, stability, electronic properties, and catalytic activities of atomically precise metal nanoclusters from first principles. Acc. Chem. Res. 2018, 51, 2793-2802.

(7) Pei, Y.; Wang, P.; Ma, Z.; Xiong, L. Growth-rule-guided structural exploration of thiolateprotected gold nanoclusters. Acc. Chem. Res. 2019, 52, 23-33.

(8) Daniel, M. C.; Astruc, D. Gold nanoparticles: assembly, supramolecular chemistry, quantum-size-related properties, and applications toward biology, catalysis, and nanotechnology. Chem. Rev. 2004, 104, 293-346.

(9) Tsukuda, T.; Tsunoyama, H.; Sakurai, H. Aerobic oxidations catalyzed by colloidal nanogold. Chem. Asian J. 2011, 6, 736-748.

(10) Zhu, Y.; Qian, H.; Jin, R. Catalysis opportunities of atomically precise gold nanoclusters. J. Mater. Chem. 2011, 21, 6793-6799.

(11) Kwak, K.; Kumar, S. S.; Lee, D. Selective determination of dopamine using quantumsized gold nanoparticles protected with charge selective ligands. Nanoscale. 2012, 4, 4240-4246.

(12) Sakai, N.; Tatsuma, T. Photovoltaic properties of glutathione-rotected gold clusters adsorbed on $\mathrm{TiO}_{2}$ electrodes. Adv. Mater. 2010, 22, 3185-3188. 
(13) Wu, Z.; Wang, M.; Yang, J.; Zheng, X.; Cai, W.; Meng, G.; Qian, H.; Wang, H.; Jin, R. Well-defined nanoclusters as fluorescent nanosensors: A case study on $\mathrm{Au}_{25}(\mathrm{SG})_{18}$. Small. 2012, 8, 2028-2035.

(14) Murray, R. W. Nanoelectrochemistry: metal nanoparticles, nanoelectrodes, and nanopores. Chem. Rev. 2008, 108, 2688-2720.

(15) Galloway, J. M.; Bramble, J. P.; Rawlings, A. E.; Burnell, G.; Evans, S. D.; Staniland, S. S. Biotemplated magnetic nanoparticle arrays. Small 2012, 8, 204-208.

(16) Du, Y.; Sheng, H.; Astruc, D.; Zhu, M. Atomically precise noble metal nanoclusters as efficient catalysts: A bridge between structure and properties. Chem. Rev. 2020, 120, 526- 622.

(17) Yao, Q.; Chen, T.; Yuan, X.; Xie, J. Toward total synthesis of thiolate-protected metal nanoclusters. Acc. Chem. Res. 2018, 51, 1338-1348.

(18) Sakthivel, N. A.; Dass, A. Aromatic thiolate-protected series of gold nanomolecules and a contrary structural trend in size evolution. Acc. Chem. Res. 2018, 51, 1774-1783.

(19) Aikens, C. M. Electronic and geometric structure, optical properties, and excited state behavior in atomically precise thiolate-stabilized noble metal nanoclusters. Acc. Chem. Res. 2018, 51, 3065-3073.

(20) Ghosh, A.; Mohammed, O. F.; Bakr, O. M. Atomic-level doping of metal clusters. Acc. Chem. Res. 2018, 51, 3094-3103.

(21) Hossain, S.; Niihori, Y.; Nair, L. V.; Kumar, B.; Kurashige, W.; Negishi, Y. Alloy clusters: Precise synthesis and mixing effects. Acc. Chem. Res. 2018, 51, 3114-3124. 
(22) Harb, M.; Rabilloud, F.; Simon, D. Structural, electronic, magnetic and optical properties of icosahedral silver-nickel nanoclusters. Phys. Chem. Chem. Phys. 2010, 12, 4246-4254.

(23) Yu, C.; Schira, R.; Brune, H.; Issendorff, B. V.; Rabilloud, F.; Harbich, W. Optical properties of size selected neutral Ag clusters: electronic shell structures and the surface plasmon resonance. Nanoscale 2018, 10, 20821-20827.

(24) Zhang, Q.-F.; Chen, X.; Wang, L.-S. Toward solution syntheses of the tetrahedral $\mathrm{Au}_{20}$ pyramid and atomically precise gold nanoclusters with uncoordinated sites. Acc. Chem. Res. 2018, 51, 2159-2168.

(25) Cook, A. W.; Hayton, T. W. Case studies in nanocluster synthesis and characterization: Challenges and opportunities. Acc. Chem. Res. 2018, 51, 2456-2464.

(26) Lei, Z.; Wan, X.-K.; Yuan, S. F.; Guan, Z.-J.; Wang, Q. M. Alkynyl approach toward the protection of metal nanoclusters. Acc. Chem. Res. 2018, 51, 2465-2474.

(27) Sharma, S.; Chakrahari, K. K.; Saillard, J.-Y.; Liu, C. W. Structurally precise dichalcogenolate-protected copper and silver superatomic nanoclusters and their alloys. Acc. Chem. Res. 2018, 51, 2475-2483.

(28) Higaki, T.; Li, Q.; Zhou, M.; Zhao, S.; Li, Y.; Li, S.; Jin, R. Toward the tailoring chemistry of metal nanoclusters for enhancing functionalities. Acc. Chem. Res. 2018, 51, 27642773.

(29) Tang, Q.; Hu, G.; Fung, V.; Jiang, D. Insights into interfaces, stability, electronic properties, and catalytic activities of atomically precise metal nanoclusters from first principles. Acc. Chem. Res. 2018, 51, 2793-2802. 
(30) Konishi, K.; Iwasaki, M.; Shichibu, Y. Phosphine-ligated gold clusters with core+exo geometries: Unique properties and interactions at the ligand-cluster interface. Acc. Chem. Res. 2018, 51, 3125-3133.

(31) Yan, J.; Teo, B. K.; Zheng, N. Surface chemistry of atomically precise coinage-metal nanoclusters: from structural control to surface reactivity and catalysis. Acc. Chem. Res. 2018, 51, 3084-3093.

(32) Ube, H.; Zhang, Q.; Shionoya, M. A carbon-centered hexagold (I) cluster supported by Nheterocyclic carbene ligands. Organometallics 2018, 37, 2007-2009.

(33) Narouz, M. R.; Takano, S.; Lummis, P. A.; Levchenko, T. I.; Nazemi, A.; Kaappa, S.; Malola, S.; Yousefalizadeh, G.; Calhoun, L. A.; Stamplecoskie, K. G.; Häkkinen, H.; Tsukuda, T.; Crudden, C. M. Robust, highly luminescent $\mathrm{Au}_{13}$ superatoms protected by N-heterocyclic carbenes. J. Am. Chem. Soc. 2019, 141, 14997-15002.

(34) Narouz, M. R.; Osten, K. M.; Unsworth, P. J.; Man, R. W. Y.; Salorinne, K.; Takano, S.; Tomihara, R.; Kaappa, S.; Malola, S.; Dinh, C. T.; Padmos, J. D.; Ayoo, K.; Garrett, P. J.; Nambo, M.; Horton, J. H.; Sargent, E. H.; Häkkinen, H.; Tsukuda, T.; Crudden, C. M. Nheterocyclic carbene-functionalized magic-number gold nanoclusters. Nat. Chem. 2019, 11, 419425.

(35) Tang, Q.; Jiang, D. Comprehensive view of the ligand-gold interface from first principles. Chem. Mater. 2017, 29, 6908-6915. 
(36) Shen, H.; Deng, G.; Kaappa, S.; Tan, T.; Han, Y.; Malola, S.; Lin, S.; Teo, B. K.; Häkkinen, H.; Zheng, N. Highly robust but surface-active: An N-heterocyclic carbene-stabilized $\mathrm{Au}_{25}$ nanocluster. Angew. Chem. Int. Ed. 2019, 58, 17731-17735.

(37) Jiang, L.; Zhang, B.; Médard, G.; Seitsonen, A. P.; Haag, F.; Allegretti, F.; Reichert, J.; Kuster, B.; Bartha, J. V.; Papageorgiou, A. C. N-heterocyclic carbenes on close-packed coinage metal surfaces: bis-carbene metal adatom bonding scheme of monolayer films on Au, Ag and Cu. Chem. Sci. 2017, 8, 8301-8308.

(38) Muñoz-Castro, A. Potential of N-heterocyclic carbene derivatives from $\mathrm{Au}_{13}(\mathrm{dppe})_{5} \mathrm{Cl}_{2}$ gold superatoms. Evaluation of electronic, optical and chiroptical properties from relativistic DFT. Inorg. Chem. Front. 2019, 6, 2349-2358.

(39) Tolman, C. A. Steric effects of phosphorus ligands in organometallic chemistry and homogeneous catalysis. Chem. Rev. 1977, 77, 313-348.

(40) Munz, D. Pushing Electrons-which carbene ligand for which application? Organometallics 2018, 37, 275-289.

(41) Gusev, D. G.; Peris, E. The Tolman electronic parameter (TEP) and the metal-metal electronic communication in ditopic NHC complexes. Dalton Trans. 2013, 42, 7359-7364.

(42) Arduengo, A. J.; Bertrand, G. Carbenes introduction. Chem. Rev. 2009, 109, 3209-3210.

(43) Nelson, D. J.; Nolan, S. P. Quantifying and understanding the electronic properties of Nheterocyclic carbenes. Chem. Soc. Rev. 2013, 42, 6723.

(44) van der Velden, J. W. A.; Bour, J. J.; Steggerda, J. J.; Beurskens, P. T.; Roseboom, M.; Noordik, J. H. Gold clusters. Tetrakis [1, 3-bis (diphenylphosphino) propane] hexagold dinitrate: 
preparation, x-ray analysis, and gold-197 Moessbauer and phosphorus-31 \{proton\} NMR spectra. Inorg. Chem. 1982, 21, 4321-4324.

(45) Shichibu, Y.; Konishi, K. Electronic properties of [core+exo]-type gold clusters: Factors affecting the unique optical transitions. Inorg. Chem. 2013, 52, 6570-6575.

(46) Kamei, Y.; Shichibu, Y.; Konishi, K. Generation of small gold clusters with unique geometries through cluster - to - cluster transformations: Octanuclear clusters with edge-sharing gold tetrahedron motifs. Angew. Chem. Int. Ed. 2011, 50, 7442-7445.

(47) Wen, F.; Englert, U.; Gutrath, B.; Simon, U. Crystal structure, electrochemical and optical properties of $\left[\mathrm{Au}_{9}\left(\mathrm{PPh}_{3}\right)_{8}\right]\left(\mathrm{NO}_{3}\right)_{3}$. Eur. J. Inorg. Chem. 2008, 1, 106-111.

(48) van der Velden, J. W. A.; Bour, J. J.; Bosman, W. P.; Noordik, J. H.; Beurskens, P. T. The electrochemical preparation of $\left[\mathrm{Au}_{9}\left(\mathrm{PPh}_{3}\right)_{8}\right]^{+}$. A comparative study of the structures and properties of $\left[\mathrm{Au}_{9}\left(\mathrm{PPh}_{3}\right)_{8}\right]^{+}$and $\left[\mathrm{Au}_{9}\left(\mathrm{PPh}_{3}\right)_{8}\right]^{3+}$. Recl. Trav. Chim. Pays-Bas 1984, 103, $13-16$.

(49) Shichibu, Y.; Kamei Y.; Konishi, K. Unique [core+two] structure and optical property of a dodeca-ligated undecagold cluster: critical contribution of the exo gold atoms to the electronic structure. Chem. Commun. 2012, 48, 7559-7561.

(50) Shichibu, Y.; Negishi, Y.; Tsukuda, T.; Teranishi, T. Large-scale synthesis of thiolated $\mathrm{Au}_{25}$ clusters via ligand exchange reactions of phosphine-stabilized $\mathrm{Au}_{11}$ clusters. J. Am. Chem. Soc. 2005, 127, 13464-13465.

(51) McKenzie, L. C.; Zaikova, T. O.; Hutchison, J. E. Structurally similar triphenylphosphinestabilized undecagolds, $\mathrm{Au}_{11}\left(\mathrm{PPh}_{3}\right)_{7} \mathrm{Cl}_{3}$ and $\left[\mathrm{Au}_{11}\left(\mathrm{PPh}_{3}\right)_{8} \mathrm{Cl} l_{2}\right] \mathrm{Cl}$, exhibit distinct ligand exchange pathways with glutathione. J. Am. Chem. Soc. 2014, 136, 13426-13435. 
(52) Shichibu, Y.; Konishi, K. HCl-Induced nuclearity convergence in diphosphine-protected ultrasmall gold clusters: A novel synthetic route to "Magic-Number" Au ${ }_{13}$ clusters. Small 2010, 6, 1216-1220.

(53) Konishi, K. Phosphine-coordinated pure-gold clusters: diverse geometrical structures and unique optical properties/responses. Struct. Bond. (Gold Clusters, Colloids and Nanoparticles I) 2014, 161, 49-86.

(54) Parr, R.G.; Yang, W. Density-Functional Theory of Atoms and Molecules. 1994, Oxford University Press, UK.

(55) Grimme, S. Semiempirical GGA-type density functional constructed with a long-range dispersion correction. J. Comput. Chem. 2006, 27, 1787-1799.

(56) a) te Velde, G.; Bickelhaupt, F. M.; van Gisbergen, S. J. A.; Guerra, C. F.; Baerends, E. J.; Snijders, J. G.; Ziegler, T. Chemistry with ADF. J. Comput. Chem. 2001, 22, 931-967; b) ADF2016, SCM, Theoretical Chemistry, Vrije Universiteit: Amsterdam, The Netherlands; http://www.scm.com.

(57) van Lenthe, E.; Baerends, E. J.; Snijders, J. G. Relativistic total energy using regular approximations. J. Chem. Phys. 1994, 101, 9783-9792.

(58) Lenthe, E. V.; Baerends, E. J. Optimized Slater-type basis sets for the elements 1-118. J. Comput. Chem. 2003, 24, 1142-1156.

(59) Becke, A. D. Density-functional exchange-energy approximation with correct asymptotic behavior. Phys. Rev. A 1988, 38, 3098-3100. 
(60) Perdew, J. P. Density-functional approximation for the correlation energy of the inhomogeneous electron gas. Phys. Rev. B 1986, 33, 8822-8824.

(61) Frisch, M. J.; Trucks, G. W.; Schlegel, H. B.; Scuseria, G. E.; Robb, M. A.; Cheeseman, J. R.; Scalmani, G.; Barone, V.; Petersson, G. A.; Nakatsuji, H.; Li, X.; Caricato, M.; Marenich, A. V.; Bloino, J.; Janesko, B. G.; Gomperts, R.; Mennucci, B.; Hratchian, H. P.; Ortiz, J. V.; Izmaylov, A. F.; Sonnenberg, J. L.; Williams-Young, D.; Ding, F.; Lipparini, F.; Egidi, F.; Goings, J.; Peng, B.; Petrone, A.; Henderson, T.; Ranasinghe, D.; Zakrzewski, V. G.; Gao, J.; Rega, N.; Zheng, G.; Liang, W.; Hada, M.; Ehara, M.; Toyota, K.; Fukuda, R.; Hasegawa, J.; Ishida, M.; Nakajima, T.; Honda, Y.; Kitao, O.; Nakai, H.; Vreven, T.; Throssell, K.; Montgomery, J. A., Jr.; Peralta, J. E.; Ogliaro, F.; Bearpark, M. J.; Heyd, J. J.; Brothers, E. N.; Kudin, K. N.; Staroverov, V. N.; Keith, T. A.; Kobayashi, R.; Normand, J.; Raghavachari, K.; Rendell, A. P.; Burant, J. C.; Iyengar, S. S.; Tomasi, J.; Cossi, M.; Millam, J. M.; Klene, M.; Adamo, C.; Cammi, R.; Ochterski, J. W.; Martin, R. L.; Morokuma, K.; Farkas, O.; Foresman, J. B.; Fox, D. J. Gaussian16, Gaussian, Inc.: Wallingford, CT, 2016.

(62) Glendening, E. D.; Badenhoop, J. K.; Reed, A. E.; Carpenter, J. E.; Bohmann, J. A.; Morales, C. M.; Weinhold, F. NBO 6.0. Theoretical Chemistry Institute, University of Wisconsin (Madison, WI, 2001, http://nbo6.chem.wisc.edu).

(63) Weigend F.; Ahlrichs, R. Balanced basis sets of split valence, triple zeta valence and quadruple zeta valence quality for $\mathrm{H}$ to Rn: Design and assessment of accuracy. Phys. Chem. Chem. Phys. 2005, 7, 3297-3305.

(64) Runge, E.; Gross, E. K. U. Density-functional theory for time-dependent systems. Phys. Rev. Lett. 1984, 52, 997-1000. 
(65) Stephens, P. J.; Devlin, F. J.; Chabalowski, C. F.; Frisch, M. J. Ab Initio calculation of vibrational absorption and circular dichroism spectra using density functional force fields. $J$. Phys. Chem. 1994, 98, 11623-11626.

(66) van Leeuwen, R.; Baerends, E. J. Exchange-correlation potential with correct asymptotic behavior. Phys. Rev. A 1994, 49, 2421-2431.

(67) Gorelsky, S. I. SWizard program. Revision 4.5, http://www.sg-chem.net.

(68) Albright, T. A.; Burdett, J. K.; Whangbo, M. H. Orbital Interactions in Chemistry. 2nd Ed. John Wiley \& Sons Inc. 2013.

(69) Mingos, D. M. P.; Wales, D. J. Introduction to Cluster Chemistry. Prentice-Hall. Englewood Cliffs. 1990.

(70) Briant, C. E.; Hall, K. P.; Mingos, D. M. P. Structural characterisation of two crystalline modifications of $\left[\mathrm{Au}_{9}\left\{\mathrm{P}\left(\mathrm{C}_{6} \mathrm{H}_{4} \mathrm{OMe}-\mathrm{p}\right)_{3}\right\}_{8}\right]\left(\mathrm{NO}_{3}\right)_{3}$ : The first example of skeletal isomerism in metal cluster chemistry. J. Chem. Soc., Chem. Commun. 1984, 5, 290-292.

(71) Weerawardene, K. L. D. M.; Pandeya, P.; Zhou, M.; Chen, Y.; Jin R.; Aikens, C. M. Luminescence and electron dynamics in atomically precise nanoclusters with eight superatomic electrons. J. Am. Chem. Soc. 2019, 141, 18715-18726.

(72) Gam, F.; Paez-Hernandez, D.; Arratia-Perez, R.; Liu, C. W.; Kahlal, S.; Saillard, J. Y.; Muñoz-Castro, A. Coinage Metal Superatomic Cores: Insights into Their Intrinsic Stability and Optical Properties from Relativistic DFT Calculations. Chem. Eur. J., 2017, 23, 11330-11337.

(73) Results obtained from a non-exhaustive search for low-energy isomers of the $\left[\mathrm{Au}_{n}\right]^{\mathrm{X}}$ systems are provided in Figure S18. 
Table of Contents Graphics and Synopsis

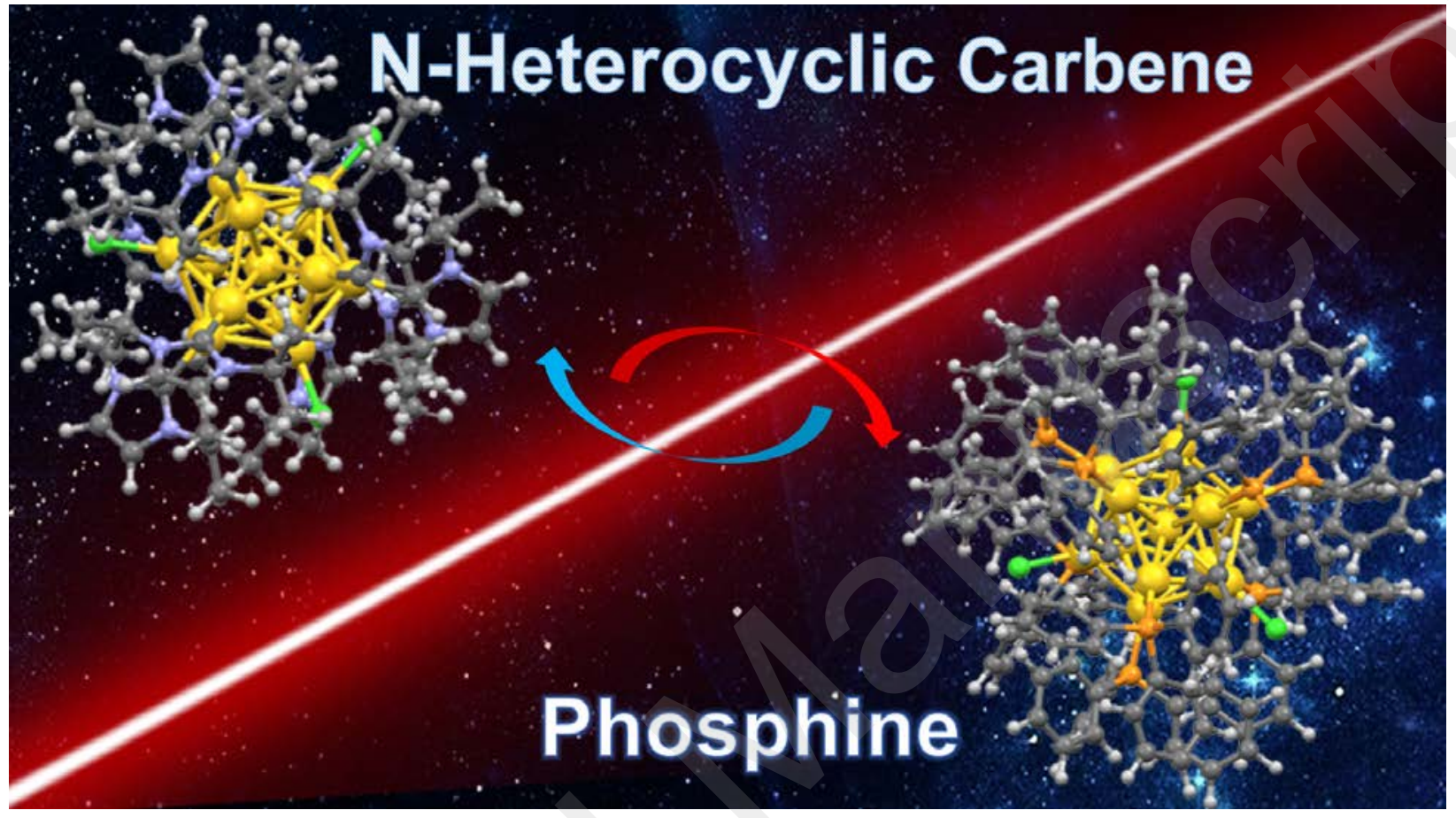

The structure and bonding of phosphine- and NHC-protected gold clusters are compared by means of DFT calculations 